DIW BERLIN

Discussion

Papers
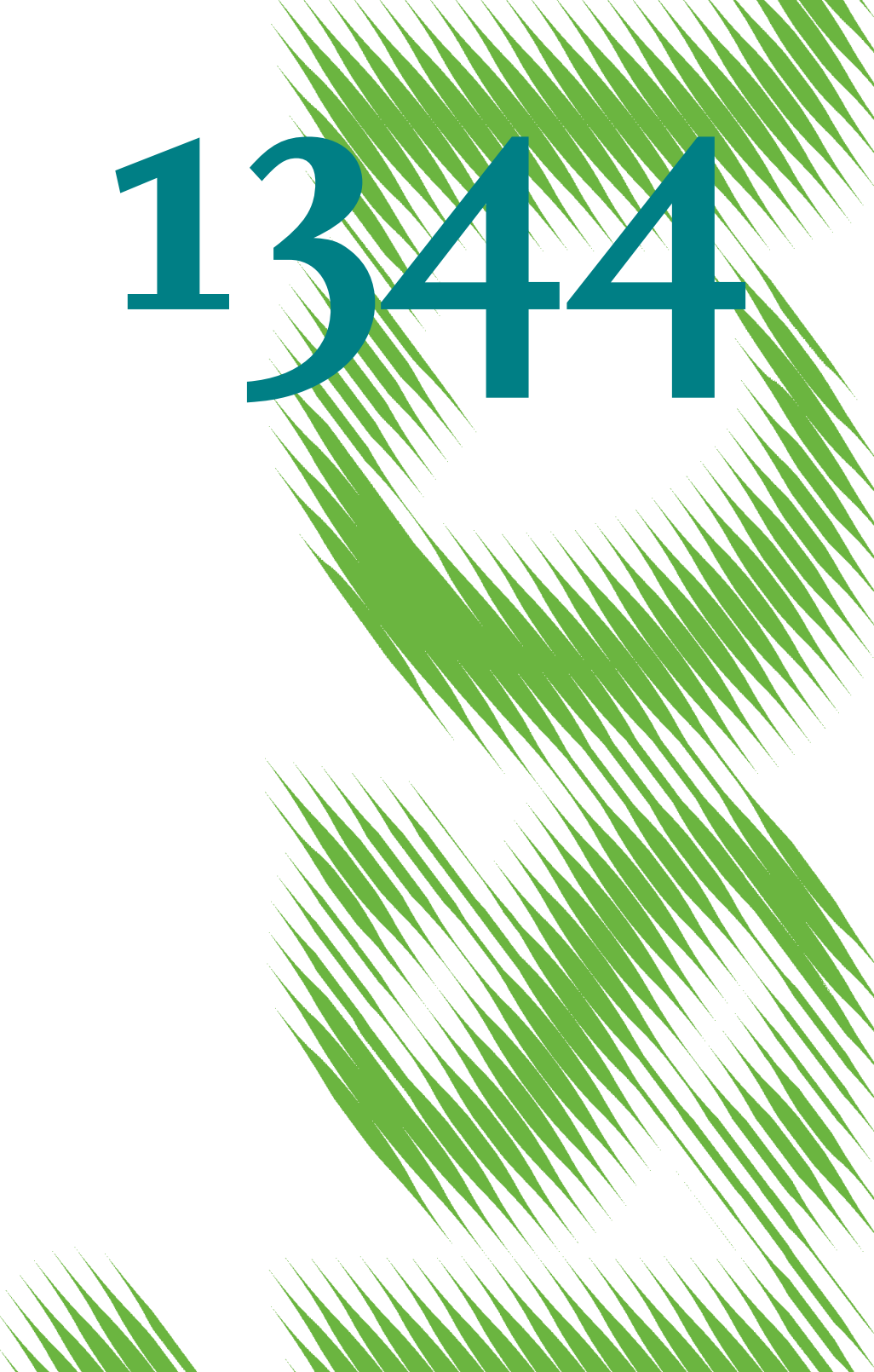

Cross-Border Banking, Bank Market Structures and Market Power

Theory and Cross-Country Evidence 
Opinions expressed in this paper are those of the author(s) and do not necessarily reflect views of the institute.

IMPRESSUM

(C) DIW Berlin, 2013

DIW Berlin

German Institute for Economic Research

Mohrenstr. 58

10117 Berlin

Tel. $+49(30) 89789-0$

Fax +49 (30) $89789-200$

http://www.diw.de

ISSN print edition $1433-0210$

ISSN electronic edition 1619-4535

Papers can be downloaded free of charge from the DIW Berlin website:

http://www.diw.de/discussionpapers

Discussion Papers of DIW Berlin are indexed in RePEc and SSRN:

http://ideas.repec.org/s/diw/diwwpp.html

http://www.ssrn.com/link/DIW-Berlin-German-Inst-Econ-Res.html 


\title{
Cross-Border Banking, Bank Market Structures and Market Power: \\ Theory and Cross-Country Evidence
}

\author{
Franziska Bremus* \\ DIW Berlin
}

October 2013

\begin{abstract}
Patterns in cross-border banking have changed since the global financial crisis. This may affect domestic bank market structures and macroeconomic stability in the longer term. In this study, I theoretically and empirically analyze how different modes of cross-border banking impact bank concentration. I use a twocountry general equilibrium model with heterogeneous banks developed by De Blas and Russ (2010) to grasp the effect of cross-border lending and foreign direct investment in the banking sector on bank market structures. The model suggests that both cross-border lending and bank FDI mitigate concentration. Empirical evidence from a linked micro-macro panel dataset of 18 OECD countries supports the theoretical predictions: higher volumes of bank FDI and of cross-border lending coincide with lower Herfindahl-indexes in bank credit markets.
\end{abstract}

Keywords: Cross-border lending, bank foreign direct investment, bank market concentration, net interest margins.

JEL Codes: E44, F41, G21

*Contact: DIW Berlin, Mohrenstr. 58, 10117 Berlin, Germany, Phone: +49 (0)30 - 89789590 , E-mail: fbremus@diw.de. I am grateful to Claudia Buch, Fabio Ghironi, Marlene Karl, Claudia Lambert, Katheryn Russ, and participants at the Annual Meeting of the European Economic Association 2012 for helpful comments on an earlier version. All errors and inconsistencies are solely my own responsibility. 


\section{Motivation}

The aim of this paper is to clarify, both theoretically and empirically, the role that different forms of cross-border banking play for concentration and market power in the banking sector. The analysis is motivated by the observation that, since the global financial crisis, patterns in international banking have changed. Banks' foreign direct investment activities have resumed after a temporary decline in many OECD countries and the average share of foreign-owned banks has been stable (Figure 1). However, cross-border lending dropped significantly and has remained at a comparatively low level. The reduction in cross-border lending reflects, most importantly, banks' need to deleverage as a result of changes in risk perceptions. In addition, policy interventions which have aimed at stabilizing domestic banking systems have contributed to credit market segmentation. ${ }^{1}$

[Figure 1 about here.]

Measures taken to stabilize financial institutions and changes in the structure of international banking in general may change domestic banking market structures in the longer term. On the one hand, the upward trend in bank FDI and large mergers and acquisitions led to concerns about increasing concentration in the banking industry - even before the crisis. On the other hand, if cross-border lending is reduced and markets get more segmented, competitive pressures in domestic banking systems may decrease. This potentially affects bank concentration and market power. Moreover, if competitive pressures are lower, bank efficiency can be subdued, with adverse effects on lending rates and consequently on firms' external financing conditions.

To date there is little evidence on the implications of cross-border banking for bank market structures. This paper, in a first step, uses a two-country general equilibrium model developed by De Blas and Russ (2010a) in order to theoretically study the effects of cross-border banking on bank concentration. The model features heterogeneous banks and different modes of international banking, namely direct cross-border lending and foreign direct investment (FDI) in the banking sector. I slightly modify the model by additionally including bank capital besides loans and deposits in the bank balance sheet. While De Blas and Russ $(2010,2013)$ theoretically study the implications of financial liberalization on banks' net interest margins, lending rates and on welfare, I focus on the implications of different modes of cross-border banking for concentration. Concentration is measured by the banking sector's Herfindahl-index and by the three-

\footnotetext{
${ }^{1}$ Recent studies present evidence for an increased homeward bias in banks' international portfolios since the crisis. This tendency is found to be partly due to policy initiatives like nationalizations, guarantees or regulatory rules that provide incentives for banks to concentrate more on their home economies (see for example Merler and Pisani-Ferry 2012, Pockrandt and Radde 2012 or Rose and Wieladek 2011).
} 
bank concentration ratio.Model simulations show that concentration decreases both for increased cross-border lending and for more bank FDI. Concerning market power the model predicts, as shown by De Blas and Russ (2010, 2013), that banks' markups rise compared to financial autarky if bank FDI is considered in the model. However, markups are unaffected by direct foreign lending.

In a second step, I empirically study how different types of international banking are linked to concentration and market power. To that goal, I use a linked micro-macro panel dataset of 18 OECD-countries for the period 1995-2009. Tentative evidence from this data shows that international banking, both in the form of foreign lending and FDI, reduces Herfindahl-indexes and three-bank concentration ratios. Using net interest margins as a proxy for banks' markups, I find that market power is positively related to bank FDI whereas it is unaffected by direct foreign lending. The empirical evidence is thus in line with the theoretical model predictions.

My work is related to different strands of literature. A large number of studies address the question how competition and concentration in the banking sector affect financial stability. ${ }^{2}$ Theoretical and empirical results are mixed. While one set of studies finds evidence that more concentrated and less competitive banking systems increase stability due to increased charter values, higher monitoring incentives or better diversification of large banks (Craig and Santos 1997, Hunter and Wall 1995, Keeley 1990, Paroush 1995), others find a negative link between concentration and financial stability. High concentration may harm financial stability, because banks in more concentrated systems may be "too important", "too connected" or "too big to fail". The resulting moral hazard enforces their risk-taking incentives and ultimately systemic risk (e.g. Mishkin 1999, Allen and Gale 2004). Cross-country evidence from Beck et al. (2006) suggests that economies with higher banking sector concentration are less likely to experience a systemic banking crisis. At the same time, more competition between banks reduces the risk of crises. Hence, a higher degree of concentration does not necessarily imply less competition (Matutes and Vives 1996). In a similar vein, Barth et al. (2004) and Beck et al. (2006) find that higher regulatory restrictions on bank entry or bank activities enhance the probability of systemic banking crises. Boyd and De Nicolo (2005) point out that banks' market power affects the risk-taking incentives of firms via lending rates. The higher banks' market power and hence lending rates, the higher are firms' risk taking incentives. Consequently, firms' probability of default rises. Summing up the competition-stability literature, Beck et al. (2010) conclude that even though there is no clear consensus, tentative evidence suggests that competition in the banking sector does not harm financial stability. I complement this strand of literature by analyzing how bank concentration and the competitive environment are affected by changes in cross-border banking activities.

\footnotetext{
${ }^{2}$ See Beck (2008) for an overview.
} 
According to the concept of granularity (Gabaix 2011), high market concentration can affect aggregate stability even without moral hazard or contagion: if some very large firms (or: banks) dominate the market and are large relative to the entire economy, idiosyncratic firm-level fluctuations can translate into aggregate volatility. Amiti and Weinstein (2013), Bremus et al. (2013) and Buch and Neugebauer (2011) study the implications of high concentration in the banking sector for fluctuations in macroeconomic aggregates. In the spirit of Gabaix (2011), these studies show that under the presence of large banks, idiosyncratic shocks at the bank-level can affect macroeconomic variables like aggregate credit supply, investment and GDP. As concentration increases, bank-level shocks can generate larger macroeconomic fluctuations that can be interpreted as increased systemic risk. However, these studies concentrate on closed economy setups and do not address the question how changes in international banking impact on banking sector concentration and market power.

Studies on the link between cross-border banking and competition find that foreign bank entry is an important determinant of bank competition. Claessens and Laeven (2004) show that both foreign bank ownership and fewer restrictions on entry or bank activities promote competitiveness. They show that more concentration does not have to coincide with less competition, and conclude that market contestability, i.e. the threat of entry by potential competitors, is more important for competitive behavior than market structures like concentration. Empirical evidence by Jeon et al. (2011) for Asia and Latin America points into the same direction. Higher foreign bank participation fosters competition in the host market, and this is the more so the more efficient the entering banks and the less concentrated the host markets are. I complement this literature by proposing a theoretical explanation of the effects of cross-border banking on concentration and competitive pressures. Moreover, besides foreign banking in the form of foreign ownership, I study the effects of cross-border lending on concentration and market power.

The remainder of the paper is structured as follows. Section 2 lays out the benchmark model with heterogeneous banks under financial autarky. Section 3 discusses the model setup as well as the simulation results for two modes of cross-border banking. In the first part, the implications of direct foreign lending are discussed, while the findings for bank FDI are presented in the second part. Section 4 presents empirical evidence for a set of 18 OECD countries, while the last section concludes and discusses policy implications. 


\section{Banking market structures in the closed econ- omy $^{3}$}

The goal of this paper is to examine how cross-border banking affects concentration and market power. But before having a look at the mechanisms at work in an open economy setup, I consider the structure of the closed economy model as a benchmark. The general equilibrium model described below was developed by De Blas and Russ (2010a) who focus on the evolution of markups after financial liberalization. I use the model in order to study the implications of cross-border banking for concentration in the banking sector.

The model features three types of agents: a representative household, a representative firm and many banks. The household consumes a final good and supplies labor and deposits to the firm. The firm produces the final good under perfect competition using labor. In order to finance the wage bill paid to workers, it borrows a credit portfolio from banks. The model replicates some important empirical regularities of the banking industry: Banks supply different types of credit under imperfect competition.

[Figure 2 about here.]

\subsection{Model setup}

Households. In the model economy, a representative consumer supplies labor, $h_{t}$ in exchange for the nominal wage $w_{t}$, and deposits his savings, $d_{t}$, at the certain deposit rate $r^{d}$ at banks. The deposit rate is risk-free, because full deposit insurance is assumed. Households are thus indifferent of where to deposit their savings. The consumer receives profit income from owning firms and banks, $\Omega$ and $\Pi$, respectively. He consumes a single final good, $q_{t}$, which is defined as the numéraire so that its price $p_{t}$ can be normalized to 1.

The representative consumer's optimization problem consists in maximizing lifetime utility

$$
u\left(q_{t}, h_{t}\right)=\sum_{t=0}^{\infty} \beta^{t}\left(\frac{q_{t}^{1-\rho}}{1-\rho}-\frac{h_{t}^{1+\frac{1}{\gamma}}}{1+\frac{1}{\gamma}}\right)
$$

subject to the budget constraint

$$
d_{t+1}+q_{t}=\left(1+r^{d}\right) d_{t}+w_{t} h_{t}+\Omega+\Pi
$$

\footnotetext{
${ }^{3}$ The model description heavily draws on a previous version of this paper which was circulated under the title "Financial Integration and Macroeconomic Stability: What Role for Large Banks?" as DIW-Discussion Paper No. 1178.
} 
where $\gamma$ is the elasticity of labor supply and $\rho$ denotes the coefficient of relative risk aversion.

Solving the households' optimization problem yields the standard Euler equation

$$
\left(\frac{q_{t}}{q_{t+1}}\right)^{-\rho}=\left(1+r^{d}\right) \beta .
$$

Firms. The representative firm demands labor, $h_{t}$, and a portfolio of loans comprising $J$ loan varieties $\left[\sum_{1}^{J} l^{d}(j)^{\frac{\epsilon-1}{\epsilon}}\right]^{\frac{\epsilon}{\epsilon-1}}=l^{d}$ in order to produce a final good, $y$, under perfect competition. Modeling loan demand based on the Dixit-Stiglitz approach of bundling varieties is a reduced form for modeling the credit market which simplifies aggregation. Gerali et al. (2010) and Huelsewig et al. (2009) take a similar shortcut. Assuming that the representative firm demands a CES-basket of loan varieties is equivalent to setting up the model such that a continuum of firms takes a single homogeneous loan from a particular bank under a discrete choice approach (see Anderson et al. (1987) and Bruggemann et al. (2012)) $)^{4}$. However, one could also interpret differentiated loans as services of different type, for example with respect to maturity or collateralization. Loans are needed because firms have to pay out the wage bill to workers before they have actually earned sales revenues. Hence, the total volume of credit demanded by the representative firm amounts to its wage payments ${ }^{5}$.

The representative firm produces the final output good $y$ using labor as the only input factor to the production function $y=A h^{1-\alpha}$. Time subscripts are dropped in the remaining analysis as the focus will be on steady state analysis. The firm's profit maximization problem can then be written as

$$
\max _{h} \Omega=A h^{1-\alpha}-w h-r \ell^{d}
$$

where $r$ denotes the lending rate and $\ell^{d} \equiv w h$, so that

$$
\Omega=A h^{1-\alpha}-(1+r) w h
$$

The first order condition determines labor demand as a function of the aggregate lending rate and the wage rate as

$$
h=\left(\frac{(1-\alpha) A}{(1+r) w}\right)^{1 / \alpha} .
$$

\footnotetext{
${ }^{4}$ For other general equilibrium models featuring imperfect competition in the banking sector and loan differentiation, see for example Mandelman (2010) and Ghironi and Stebunovs (2010).

${ }^{5}$ The focus of this paper is to analyze the implications of shocks to large banks for the aggregate stability of credit. Therefore, I do not explicitly model why financial intermediaries exist. The objective here is to take the observation of a skewed bank size distribution as given and study the implications of changes in international banking activities on concentration.
} 
The optimal demand for loans in niche $j$ derives from the firm's cost minimization problem and is given by

$$
l^{d}(j)=\left[\frac{r(j)}{r}\right]^{-\epsilon} \ell^{d}
$$

with $\ell^{d}=w h$. Loan demand in niche $j$ positively depends on total loan demand $\ell^{d}$, and negatively depends on the lending rate in niche $j$ relative to the aggregate average lending rate $r$. The corresponding Dixit-Stiglitz aggregate interest rate amounts to

$$
r=\left[\sum_{1}^{J} r(j)^{1-\epsilon}\right]^{\frac{1}{1-\epsilon}}
$$

(see Appendix A.1 and A.2 for the derivations).

Banks. The model features a large number of banks that differ in terms of their efficiency of lending and hence in their size. Similar to the modeling of consumer preferences in the Dixit-Stiglitz framework, there is a fixed number of credit niches $j=1, \ldots, J$. This credit market fragmentation is in line with the empirical evidence: although international lending has steadily increased since the mid-1990s, small and medium enterprises still face significant differences in lending rates across the Euro area (Allen et al. 2011).

Bank profits consist of interest income net of funding costs

$$
\Pi(j)=r(j) l^{s}(j)-r^{d} d(j)-r^{e} e \cdot d(j)=r(l) l^{s}(j)-d(j)\left[r^{d}+r^{e} e\right],
$$

where bank $j$ 's technology is given by $l^{s}(j)=\frac{(1+e) d(j)}{c(j)}$; the bank funds its loan supply by deposits, $d(j)$, and equity, $e d(j)$. Following Hellmann et al. (2000) I express bank capital as a percentage of deposits, such that $e=e(j) / d(j)$. The bank's non-interest cost of lending is denoted $c(j) \geq 1$, and can be interpreted as a monitoring or screening cost or as the cost of management and technology. As in Bremus et al. (2013), the interest rate on bank equity exceeds the deposit rate by a tax on corporate profits, $r^{e}=r^{d}(1+\tau)$. Moreover, I assume that banks hold equity because they are obliged by the regulator to fund part of their lending with own funds. The higher the cost $c(j)$, the more deposits and equity are needed to lend out a given amount $l^{s}(j)$.

Within each credit niche, a number of $n$ rival banks compete for supplying loans to firms. Banks' loan differentiation can be interpreted as geographical fragmentation, or banks' specialization for specific market segments, e.g. with respect to firm size or industry (see Carletti et al. 2007).

Banks differ in their efficiency of extending credit. Each of the $n$ competitors in niche $j$ draws an efficiency parameter $z_{k}(j)$ from a truncated Pareto distribution

$$
F(z)=\operatorname{Pr}(z \leq y)=\frac{1-z_{0}^{\theta} y^{-\theta}}{1-z_{0}^{\theta}}
$$


where $z \in\left(z_{0}, 1\right]$ is a bank's ability to transform deposits to loans. The efficiency parameter $z_{k}(j)$ can take on values on the interval $(0,1]$ only, because the bank's noninterest cost parameter $c(j)=1 / z(j)$ which is defined on the interval $\left[1,1 / z_{0}\right)$ has to be such that the lending rate $r(j)$ is never smaller than the bank's funding cost.

In each niche $j$, banks have some degree of market power and compete in Bertrand fashion for loan demand. That is, they undercut lending rates $r(j)$ of their local rivals until the lowest-cost bank absorbs the entire loan demand $l^{d}(j)$ in the niche. Ranking banks with respect to their cost draws in ascending order such that $c_{1}(j)<c_{2}(j)<$ $\ldots<c_{n}(j)$, unit costs in niche $j$ are determined by the lowest-cost bank and are thus given by $c_{1}(j)=\min \left\{c_{k}(j)\right\}$.

The maximum possible markup that a bank can charge without losing all demand to its competitors from neighboring niches results from the bank's profit maximization (see Appendix A.2.3). It is given by the Dixit-Stiglitz-markup $\bar{m}=\frac{\epsilon}{\epsilon-1}$. The corresponding optimal lending rate is given by the product of this markup and the marginal cost of lending

$$
r(j)^{u}=\frac{\epsilon}{\epsilon-1} \frac{r^{d}+r^{e} e}{1+e} c(j)
$$

where marginal cost, $\frac{r^{d}+r^{e} e}{1+e} c(j)$, consists of the bank's funding cost times its non-interest cost.

However, the maximum markup can be charged only if the second best bank in niche $j$ has a cost parameter that is sufficiently high. More precisely, the maximum markup can be charged only if $c_{2}(j) \geq \bar{m} c_{1}(j)$. Otherwise, the maximum markup the lowest-cost bank in niche $j$ can charge is limited by $c_{2}$ and given by the cost-ratio $m(j)=\frac{c_{2}(j)}{c_{1}(j)}$. As a consequence, banks' lending-to-deposit-rate spreads are endogenous and determined by the gap between the cost parameters of the first and the second best bank in each niche $j$.

Banks set optimal lending rates in niche $j$ charging the endogenously determined markup over marginal costs:

$$
r(j)=\min \left\{\frac{c_{2}(j)}{c_{1}(j)} ; \bar{m}\right\} \frac{\left(r^{d}+r^{e} e\right) c_{1}(j)}{1+e} .
$$

Lending rates and wages determine loan demand $l^{d}(j)$. In equilibrium, the loan market clears, so that loan demand equals loan supply $l^{d}(j) \equiv l^{s}(j)$.

\subsection{Steady State and Aggregation}

The consumer optimization problem yields

$$
\begin{aligned}
r^{d} & =\frac{1-\beta}{\beta} \\
h^{1 / \gamma} & =q^{-\rho} w
\end{aligned}
$$


where (8) derives the constant deposit rate from the Euler equation, and (9) is labor supply. The household supplies more labor if the wage, $w$, increases or if consumption, $q$ is reduced.

In order to compute the steady state, all variables are expressed in terms of wages, $w$, and lending rates, $r$. Given that optimal lending rates can be computed directly from the cost parameters, the steady state values of the model variables can be obtained once they are expressed as functions of the lending rate and parameter values only. ${ }^{6}$

Concerning aggregation, the loan basket demanded by the representative firm is given by the CES-aggregate over all niches $j, l^{d}=\left[\sum_{1}^{J} l^{d}(j)^{\frac{\epsilon-1}{\epsilon}}\right]^{\frac{\epsilon}{\epsilon-1}}$. The representative firm's loan demand $l^{d}$ equals the aggregate loan volume $\ell=l^{d}=w h$. Deposit markets are assumed to be perfectly competitive. Thus, the volume of deposits, $d(j)=l(j) c_{1}(j) /(1+e)$, results directly from optimal loan demand $l(j)$ and costs $c_{1}(j)$. As full deposit insurance is assumed, consumers are indifferent as to which bank houses their savings. In the aggregate, total deposits are determined by the sum across all niches $j, D=\sum_{j} d(j)$.

\subsection{Calibration}

Table 1 summarizes the parameter values used in the simulation exercises below. The elasticity of substitution between credit varieties, $\epsilon$, is backed-out from the maximum markups in the regression sample of banks from 18 OECD countries. In analogy to the theoretical model, net interest income as a percentage of earning assets, i.e. the net interest margin, can be employed as a proxy for banks' markups. ${ }^{7}$ The maximum net interest margin amounts to approximately 30 percent in the sample of OECD countries for the period 1995-2009. This yields an elasticity of substitution of $\epsilon=\bar{m} /(1-\bar{m})=1.3 / 0.3=4.3$. Ghironi and Melitz (2005) and De Blas and Russ (2010b) lay out the theoretical conditions for the relation between the intra-temporal elasticity of substitution between varieties, $\epsilon$, and the dispersion parameter of the Pareto distribution, $\theta$. They show that $\theta \geq \epsilon-1$ has to be satisfied to guarantee a meaningful solution for the aggregate price, or in the here described setup the aggregate lending rate, $r$. In order to fulfill these theoretical conditions, I set $\theta=\epsilon=4.3$ in the simulations reported below. The subjective discount factor, $\beta$, is set to 0.98 such that the risk-free deposit rate amounts to 2 percent. Assuming a risk premium of 4 percent, the net interest rate on bank equity is set to 0.06 .

[Table 1 about here.]

\footnotetext{
${ }^{6}$ A step-by-step derivation of the steady state can be found in Appendix A.3.

${ }^{7}$ For the details on the relationship between the markup and the net interest margin, see De Blas and Russ (2010a).
} 
The rest of the parameter values are standard and taken from De Blas and Russ (2010a). I simulate the model 1000 times and average over the 1000 simulated economies for the results discussed in the following sections.

\subsection{The distributions of costs, markups, loan rates, and loans}

Let us first look at the model outcomes for the distributions of the variables of interest. Figure 3 plots both the empirical probability density functions (PDFs) and the corresponding cumulative distribution functions (CDFs) for non-interest costs, markups, lending rates and the resulting loan volumes across niches $j$. The PDF of the costs of active banks in niche $j$ shows that only a small fraction of active banks dispose of very low costs close to $c=1$. For lending rates - the product of marginal costs and markups - the PDF resembles the PDF of non-interest costs, but is tilted more to the right which is due to the shape of the distribution of markups.

[Figure 3 about here.]

The distribution of loan volumes has a fat right tail and resembles the empirical distribution of loan volumes in Figure 2. Loan volumes are interpreted here as a proxy for bank size. The model features a skewed distribution of bank sizes with the bulk of banks being small to mid-sized while some banks are very large and possess large market shares. Hence, the bank market structure in the model resembles the empirical distribution seen above with high skewness and consequently high concentration.

Under the Pareto-distributed efficiency parameters $z_{k}(j)$, Figure 3 reveals that markups have a Pareto-shape: The frequency of markups decays continuously from low markups up to the maximum Dixit-Stiglitz markup $\bar{m}=1.3$. At the maximum markup, the PDF displays a kink. As contestability increases, the probability of observing maximum markups falls. The derivation of the theoretical distribution of the markup can be found in the Appendix. It shows that, indeed, markups follow a Pareto distribution as in Bernard et al. (2003) and De Blas and Russ (2010b). The distribution of markups under Pareto-efficiency draws is independent of the number of rivals per niche, $n$. Hence, the distribution of markups should not change in response to a change in the number of potential rivals and hence contestability in the financial sector.

\subsection{Contestability and concentration in the closed economy}

Which impact does regulatory policy have on market structures in the closed economy setup? If entry barriers in the banking sector are lifted, how does the following decline in the number of potential rivals per niche - i.e. the reduction in contestability - impact on concentration and borrowing conditions for firms? 
Table 2 illustrates that as the number of rivals per niche decreases from $n=100$ to $n=2$, the Herfindahl-index increases from 0.005 to 0.025 . At the same time, the market share of the three largest banks in the credit market significantly rises from about 10 - 15\%. Hence, when contestability and competitive pressures get less intense, the big banks get bigger; concentration in the banking sector rises, and market shares across niches become more unequal. Due to the reduction in contestability, banks' efficiency falls which is reflected by an increase in non-interest costs. Consequently, the overall lending rate $r$ rises. The increase in lending rates makes borrowing more expensive, such that aggregate loan demand falls.

[Table 2 about here.]

\section{Cross-border banking and market structures: The two-country model}

Having seen the key features and implications of the model under financial autarky, let us now have a look at the model implications for the effects of cross-border banking on market structures. As discussed above, while foreign lending has decreased in many OECD countries since the crisis, the upward trend in bank FDI has resumed.

This section theoretically discusses how concentration and market power in the banking sector change under different regimes of international banking. First, the case of arms-length cross-border lending will be analyzed. In this scenario, cross-border banking is modeled such that domestic banks in each credit niche $j$ face not only competition from their $n-1$ domestic rivals, but also from the $n$ foreign rival banks that produce the corresponding credit variety $j$ abroad. Second, the case of FDI in the financial sector, i.e. the presence of foreign owned banks, will be assessed. In this setup, foreign banks may merge with domestic ones in their niche $j$, so that local lending via foreign subsidiaries of multinational banks is allowed for.

\subsection{Direct cross-border lending}

The model economy is now opened up to cross-border lending. There are two regions, country $H$ and country $F$, that are linked via financial markets, namely by direct foreign lending between banks and firms. The two economies are set up as under financial autarky. However, credit markets are more contestable, because banks in each niche compete with foreign rivals for loan demand now. 


\subsubsection{Model setup under direct cross-border lending}

Let us first concentrate on two symmetric economies. In both countries, $H$ and $F$, banks draw their efficiency parameters from a Pareto distribution as before, so that we can rank banks according to their efficiency (or:cost) draws. This allows to single out the two lowest-cost banks in each country, namely $c_{1 h}(j)$ and $c_{2 h}(j)$ in country $H$ and $c_{1 f}(j)$ and $c_{2 f}(j)$ in country $F$. As all banks that offer credit variety $j$ compete with each other, a new cost structure evolves in both countries if cross-border lending is possible. Opening up the economy to international lending is thus similar to an increase in the number of rivals per niche, $n$, which was studied for the close economy case above.

The lowest-cost bank in each country is determined by taking the minimum of the cost of the best domestic bank and the best foreign bank. The latter incurs an additional cost due to distance, $\delta_{i} \geq 1$. Bruggemann et al. (2012) show that foreign lending is more costly than domestic lending due to additional costs that arise from information gathering in the foreign market, for example in the process of contracting, monitoring or screening. Including the additional cost from lending abroad, the cost parameter of the bank that supplies the whole niche $j$ in country $H$ is given by $c_{1 h}^{L L}=$ $\min \left\{c_{1 h}, \delta_{f} c_{1 f}\right\}$ and analogously for country $F$. The second best bank in each niche in country $H$, which limits the size of the markup that can be charged by the active bank, is determined by $c_{2 h}^{L L}=\min \left\{\max \left[c_{1 h}, \delta_{f} c_{1 f}\right], \min \left[c_{2 h}, \delta_{f} c_{2 f}\right]\right\}$. Thus, bank $j$ can supply credit in zero, one, or two niches depending on its cost relative to its foreign competitor and the distance factors $\delta_{h}, \delta_{f}$.

Using the new cost structure in both countries, markups and lending rates are computed as in the autarky case above. Note that if the distance factors are the same in both countries and if they are equal to one, i.e. if banks can lend to firms abroad at no additional cost, costs and hence markups and lending rates are exactly the same in both countries. The best bank always supplies the entire market $j$, that is in both Home and Foreign, and is limited in its setting of the markup by the second internationally best bank.

In order to derive loan volumes and ultimately measures of concentration, the steady state of the model has to be solved for. Solving for the equilibrium prices and quantities works in analogy to the autarky case. However, the consumer budget constraints are extended by profits banks make abroad and amount to

$$
\begin{aligned}
& q_{h}=w_{h} h_{h}+\Omega_{h}+\Pi_{h}^{h}+d_{h} r_{h}^{d}+\Pi_{h}^{f}-\Pi_{f}^{h} \\
& q_{f}=w_{f} h_{f}+\Omega_{f}+\Pi_{f}^{f}+d_{f} r_{f}^{d}+\Pi_{f}^{h}-\Pi_{h}^{f}
\end{aligned}
$$

where $\Pi_{f}^{h}$ are profits made by foreign banks in $H$ while $\Pi_{h}^{f}$ are profits made by home banks in $F$. The balance of payments can be written as

$$
n x_{h}=q_{h}^{f}-q_{f}=\Pi_{f}^{h}-\Pi_{h}^{f}
$$


and goods market clearing in the open economy is given by

$$
y_{i}=q_{i}+n x_{i}
$$

for country $i=H, F$. Hence, an export surplus in $H$ is financed by positive net profits of foreign banks operating in $H$. If banks' profits are different in $H$ and in $F$, then trade does not have to be balanced.

The equilibrium allocation in the open economy can be determined by proceeding in three steps. In a first step, firms' labor demand is determined as in the autarky case since labor is assumed to be immobile across countries (see equation (3)). Deposits in each niche can be computed as

$$
d_{i}(j)=l_{i}(j) c_{1 i}(j) /(1+e)=\left(\frac{r_{i}(j)}{r_{i}}\right)^{-\epsilon} w_{i} h_{i} \frac{c_{1 i}(j)}{(1+e)}
$$

for $i=H, F$.

Second, the representative firms' profits are given by

$$
\Omega_{i}^{F}=A_{i} h_{i}^{1-\alpha}-w_{i}\left(1+r_{i}\right) h_{i}
$$

while banks' profits have to be aggregated over all niches and countries. Domestic and foreign profits of each bank $j$ from country $H$ are denoted $\Pi_{h}^{h}(j)$ and $\Pi_{f}^{h}(j)$. They amount to

$$
\begin{aligned}
& \Pi_{h}^{h}(j)=r_{h}(j)\left(\frac{r_{h}(j)}{r_{h}}\right)^{-\epsilon} w_{h} h_{h}-\left(r_{h}^{d}+r_{h}^{e}\right) d_{h}(j) \\
& \Pi_{f}^{h}(j)=r_{f}(j)\left(\frac{r_{f}(j)}{r_{f}}\right)^{-\epsilon} w_{f} h_{f}-\left(r_{f}^{d}+r_{f}^{e}\right) d_{f}(j)
\end{aligned}
$$

and analogously for domestic and foreign profits for the banks from $F, \Pi_{f}^{f}(j)$ and $\Pi_{h}^{f}(j)$. Note that the best bank in niche $j$ - either from $H$ or from $F$ - may supply credit in both countries. Deposits for credit supply in niche $j$ are supplied locally as they are entirely determined by credit demand and the cost of the best bank. If there are no additional costs from lending abroad, i.e. if $\delta_{h}=\delta_{f}=1, c_{1}^{L L}(j)$ is the same in both $H$ and $F$. Consequently, deposits are determined by local credit demand so that $d_{h}(j)=\frac{l_{h}(j) c_{1}^{L L}(j)}{1+e}$ and $d_{f}(j)=\frac{l_{f}(j) c_{1}^{L L}(j)}{1+e}$.

In a third step, bank profits as well as deposits are aggregated across all niches $j$. Hours worked, output and firm profits do not have to be aggregated any further as the model is simplified by the assumption that there is one representative firm.

Finally, take the consumer budget constraints and substitute the labor supply equation (see (16) in the Appendix) for $q$

$$
\begin{aligned}
& \left(w_{h} h_{h}^{-1 / \gamma}\right)^{\frac{1}{\rho}}=w_{h} h_{h}+d_{h} r_{h}^{d}+\Omega_{h}+\Pi_{h}^{h}+\Pi_{h}^{f}-\Pi_{f}^{h} \\
& \left(w_{f} h_{f}^{-1 / \gamma}\right)^{\frac{1}{\rho}}=w_{f} h_{f}+d_{f} r_{f}^{d}+\Omega_{f}+\Pi_{f}^{f}+\Pi_{f}^{h}-\Pi_{h}^{f}
\end{aligned}
$$


so that a system of two equations in the two unknown wage rates, $w_{h}$ and $w_{f}$, results. The system is solved using a non-linear equation solver.

\subsubsection{Simulation results}

Figure 4 plots the distribution of the variables of interest for the international lending scenario against the benchmark of a closed economy. A look at the CDFs reveals that the autarky-case stochastically dominates the cross-border lending scenario for costs and lending rates as in De Blas and Russ (2010). That is, the probability of observing high realizations of these two variables is higher in autarky than in the open economy with direct cross-border lending. Hence, both costs and lending rates decline if foreign banks participate in the domestic credit markets. This can also be seen from the PDFs where the probability mass shifts to left, i.e. towards lower cost-realizations. The simulation results show that all 1000 average lending rates are lower under direct cross-border lending in both $H$ and $F$, so that firms are better off under internationally integrated loan markets.

Concerning lending volumes, the PDF in Figure 4 illustrates that they do not change by much after opening up the economy. On average, markups remain the same as in the closed economy. The distribution of loan volumes is somewhat more tilted towards its mean: middle realizations are observed somewhat more frequently while the very large realizations get a little less frequent. Interpreting loan volumes as a proxy for banks' size, I obtain that opening up the economy to international lending yields a more equal distribution of bank sizes and hence less concentration. The Herfindahlindex noticeably decreases, by 25 percent, after opening up the economy to foreign lending. This is similar to what was observed for the closed economy when increasing contestability in the banking sector. As seen below, the reduction in concentration is supported by the empirical evidence for OECD countries. The small change in lending volumes results from the fact that both, sectoral lending rates, $r(j)$, and aggregate the lending rate $r$ fall under direct foreign lending while the total demand for loans by the representative firm, i.e. the wage bill, is not significantly altered. As a consequence, the change in the distribution of sectoral loan demand $l(j)$ is small. Overall, in the scenario of foreign bank participation, aggregate credit increases by $1 \%$ on average in all of the 1000 simulated economies.

[Figure 4 about here.]

When it comes to cross-border lending, the model implies that half of the niches in each country are supplied by foreign banks if countries are symmetric and if banks do not incur any additional costs when lending abroad. At the same time, the share of cross-border lending in total lending is smaller with approximately 40 percent, meaning that banks supplying market niches abroad have smaller lending volumes in the foreign 
market than domestic banks, on average. Finally, having a look at aggregate crossborder lending, the simulation results reveal that concentration is higher in the crossborder credit market than in the domestic credit market. Hence, the most efficient banks that are competitive enough to lend in the foreign market assume high market shares.

If it is costly for banks to lend abroad, e.g. due to transaction or information costs related to international lending, the distance factor is larger than one. As a consequence, the share of niches supplied by foreign banks as well as the share of cross-border lending in total lending decreases in the two countries. For example, if banks from both countries face distance costs of 10 percent, the fraction of niches supplied by foreign banks drops from 50 percent to 40 percent while the share of cross-border credit flows in total credit drops to roughly 30 percent. If information frictions or barriers to entry into foreign markets increase, for example due to financial protectionism, foreign lending gets less profitable such that banks rather concentrate on their domestic markets. The higher the barriers to lending abroad, the lower are competitive pressures from foreign bank participation. Hence, as discussed above, bank efficiency falls and lending rates increase so that the financing conditions for firms get less favorable.

\subsection{FDI in the banking sector}

In contrast to the scenario with direct cross-border lending, the following setup looks at a world where banks in each niche can engage in FDI by merging with foreign banks that are active in the same market niche $j$ abroad. The multinational bank can then extend credit via its local affiliate in the foreign country.

Empirical evidence for Europe reveals that the best, i.e. the most productive, foreign banks tend to take over the best domestic banks in each market segment (Vander Vennet and Gropp 2003). The literature on bank mergers and acquisitions finds that mergers have resulted in efficiency gains (DeYoung et al. 2009). Based on these findings, foreign takeovers are modeled as follows (De Blas and Russ 2010a). Having drawn their efficiency parameters from the Pareto-distribution as before, the best international bank in niche $j$ takes over the best bank in niche $j$ abroad by paying a takeover fee that is sufficiently high to make the foreign target bank at least as well off as without the cross-border merger. The merged bank then serves the foreign market under a new, mixed $\operatorname{cost} c_{1}^{M}(j)=c_{1 f}(j)^{1 / \delta_{F D I}} c_{1 h}(j)^{1-\left(1 / \delta_{F D I}\right)}$ because it cannot entirely establish its production technology abroad. The domestic market of the parent bank is served at the same cost as before, namely at $c_{1}$. As it is only meaningful that active banks merge, i.e. the lowest-cost ones, the cost structure of the second-best banks remain the same as under autarky. Overall, costs decrease when opening up the economy 
to foreign mergers and acquisitions, because costs either remain at $c_{1}(j)$ or drop down to $c_{1}^{M}(j)$.

\subsubsection{Model setup under bank FDI}

The open economy equilibrium with bank FDI can be solved for very similarly to the cross-border lending case. The only difference concerns takeover fees that are paid to the target bank by the lowest cost bank in niche $j$, i.e. the parent bank of the merger.

Following De Blas and Russ (2010a), the buyout price offered to the target has to be at least as high as the profit the target bank would earn without merging in the open economy. Both the parent and the target take interest rates under bank FDI in all other niches as given. The resulting buyout fee in niche $J$ is then given by

$$
\begin{aligned}
V(j) & =w h \max \left\{r^{a u t}(j)\left(\frac{r^{a u t}}{r_{f d i}}\right)^{-\epsilon}-\frac{\left(r^{d}+r^{e} e\right) c_{1}(j)}{1+e}\left(\frac{r^{a u t}}{r_{f d i}}\right)^{-\epsilon}, 0\right\} \\
& =\max \left\{\left[r^{a u t}(j)-\frac{\left(r^{d}+r^{e} e\right) c_{1}(j)}{1+e}\right] l^{d}(j), 0\right\}
\end{aligned}
$$

where $r^{\text {aut }}(j)$ is the autarky-lending rate that the home bank would charge if there were no takeovers at all while $r_{f d i}$ is the aggregate lending rate that the market participants take as given under FDI-liberalization where takeovers occur whenever $C_{1 i}(j)<C_{1 k}(j)$, where $i, k=F, H$ and $i \neq k$.

Moreover, the consumers' budget constraints now include profits net of the aggregated takeover fees $V_{h}$ and $V_{f}$ :

$$
\begin{aligned}
& q_{h}=w_{h} h_{h}+\Omega_{h}+\Pi_{h}^{h}+d_{h} r_{h}+\Pi_{h}^{f}-\Pi_{f}^{h}+V_{h}-V_{f} \\
& q_{f}=w_{f} h_{f}+\Omega_{f}+\Pi_{f}^{f}+d_{f} r_{f}+\Pi_{f}^{h}-\Pi_{h}^{f}+V_{f}-V_{h}
\end{aligned}
$$

and hence net exports can be expressed as

$$
\begin{aligned}
& n x_{h}=\left(\Pi_{f}-V_{h}\right)-\left(\Pi_{h}^{f}-V_{f}\right) \\
& n x_{f}=\left(\Pi_{h}^{f}-V_{f}\right)-\left(\Pi_{f}^{h}-V_{h}\right) .
\end{aligned}
$$

The aggregate resource constraint, $y_{h}+y_{f}$, is fulfilled if

$$
y_{h}+y_{f}-\left(w_{h} h_{h}+w_{f} h_{f}+\Omega_{h}+\Pi_{h}^{h}+r_{h} d_{h}+n x_{h}+\Omega_{f}+\Pi_{f}^{f}+r_{f} d_{f}+n x_{f}\right)=0 .
$$

Since $V_{h}$ and $V_{f}$ appear in both the consumers' budget constraints $q_{h}$ and $q_{f}$, and the expression for net exports, $n x_{h}$ and $n x_{f}$, they cancel out in the aggregate resource constraints. Thus, the resource constraints are the same in the cross-border lending and in the FDI scenario. 


\subsubsection{Simulation results}

Figure 5 compares the distribution of non-interest costs, markups, lending rates and lending volumes under bank FDI to the case of financial autarky. It shows that, for the non-interest costs, the closed economy case stochastically dominates the CDF under FDI, whereas for the markup, the CDF under FDI dominates the CDF under autarky. Intuitively, this means that markups increase if banks engage in FDI. This is explained as follows. In those niches where the markup in the closed economy is at its optimum, i.e. $m(j)^{A U T}=\bar{m}$, it will remain the same when FDI is allowed for. This is because the spread between the lowest and the second lowest cost stays at least equal or gets larger under FDI, and $m(j)$ is already at the optimal Dixit-Stiglitz level which depends only on the constant elasticity of substitution between varieties, $\epsilon$. In those niches where the markup in the closed economy is smaller than the Dixit-Stiglitz markup $\bar{m}$, it stays the same or increases if bank FDI takes place, since the cost of the merged bank is lower than the cost under autarky $\left(c_{1}^{M}(j)<c_{1}(j)\right)$, so that the spread between $c_{2}(j)$ and the lowest cost grows. Hence, $m(j)^{F D I}$ is either the same as $m(j)^{A U T}$ or it is larger, implying that average markups must increase. In fact, all of the 1000 average markups are higher if bank FDI is allowed for.

[Figure 5 about here.]

For the lending rate, however, the CDFs for the FDI and the autarky-case are nearly identical. There is no single average lending rate which is higher after allowing for FDI in the banking sector. Thus, firms do not incur higher financing costs even though markups increase. For those niches where the maximum markup has been charged under autarky already, lending rates are given by $r(j)=c_{1}(j) \bar{m} \frac{r^{d}+r^{e} e}{1+e}$ which implies that borrowing in those niches may get cheaper as $c_{1}^{M}(j)<c_{1}(j)$. In the other niches where markups have been less than the maximum, FDI has no effect on lending rates, given that lending rates are determined by $r(j)=c_{2}(j) \frac{r^{d}+r^{e} e}{1+e}$ and the cost parameter of the second best bank, $c_{2}(j)$, stays the same. Hence, the overall lending rate $r$ will fall a little due to the niches where $\bar{m}=m^{A U T}(j)$, but it cannot increase, since in the remaining niches, it stays the same as in the closed economy given that $c_{2}$ is the same as before.

Let us now look at the effects of bank FDI on bank market structures. Setting the distance factor under FDI, $\delta_{F D I}$, equal to 2 for both countries $H$ and $F$, the simulation results show that the Herfindahl-index drops by 13 percent when opening up. Hence, concentration drops significantly less than under direct cross-border lending, the reason being that lending rates drop by less in the FDI scenario such that loan volumes react less. While half of the number of niches are supplied by foreign banks, the share of cross-border in total lending in both country $H$ and $F$ is just one fifth. 
Comparing the scenario of FDI with foreign lending and financial autarky, the distributions of costs point to the fact that banks are least efficient under autarky. As the economy is opened up to international lending and contestability increases, active banks in each niche get more efficient. If banks do not incur additional costs when lending abroad, costs are lowest under cross-border lending. In the FDI scenario, costs are reduced compared to autarky, but less than under direct foreign lending, because merged banks supply under the mixed $\operatorname{cost} c_{1}^{M}(j)>c_{1}^{L L}(j)$.

Concerning markups, the distribution under the FDI scenario stochastically dominates the ones under autarky and under direct cross-border lending. Hence, markups are highest under FDI. However, the increased markups after foreign takeovers have no negative implications for the lending costs of firms. Lending rates under FDI are even a little lower than under autarky. Why can markups be higher under FDI at the same lending rate as under autarky? The increase in markups is due to the fact that efficiency of the best banks in each niche picks up while the second best rival's cost stays the same. Consequently, the gap between the best and the second best bank in niche $j$ grows, thus automatically allowing for higher markups ${ }^{8}$.

\subsection{Empirical predictions}

Summing up the implications of international banking for concentration and market power, three main hypotheses follow from the theoretical model:

1. Cross-border bank lending leads to higher competitive pressures in the credit market. As a consequence, banks' market shares in the domestic market get more similar, so that concentration decreases.

2. More FDI in the banking sector increases the efficiency of lending and yields more similar credit market shares. Hence, the degree of banking market concentration falls.

3. Bank FDI increases banks' net interest margins due to efficiency gains, while cross-border lending does not matter for banks' market power.

The next section aims at testing these predictions that derive from the model simulations using a linked micro-macro panel dataset for 18 OECD countries.

\footnotetext{
${ }^{8}$ This result is driven by the specific modeling of FDI in the banking sector. Other ways of modeling bank FDI can deliver different results.
} 


\section{Cross-country evidence on international banking and market structures}

Having discussed how cross-border banking affects concentration and market power in theory, I now turn to the empirical analysis. First, I test whether cross-border lending and bank FDI are related to lower banking sector concentration, as suggested by the model. Second, the links between cross-border lending, bank FDI and banks' net interest margins will be analyzed.

Table 3 presents descriptive evidence for bank market structure in the OECD countries using bank-balance sheet data for the period 1995-2009 from the Bankscope database. The figures show that, since the beginning of the 2000s, the top 1 percent of banks hold about 70 percent of bank assets in the OECD, while this share increases to more than 90 percent for the largest 10 percent of banks in the sample. ${ }^{9}$ Hence, the banking market in OECD countries is highly concentrated with a few large, systemically important financial institutions (SIFIs) which are strongly involved in cross-border activity. This observation is in line with the theoretical model presented above: the theoretical bank size distribution is highly skewed to the right with a few large banks dominating the market (Figure 3). Moreover, only the most efficient and hence the biggest banks are active internationally in the model.

[Table 3 about here.]

In order to investigate how different measures of cross-border banking are linked to concentration and banks' net interest margins, I combine bank-level with macroeconomic data. Table 4 presents summary statistics for the regression sample. Bank-level information for the period 1995-2009 comes from the Bankscope-database. I compute Herfindahl-indexes using data on banks' total assets and total netloans to measure concentration. Three-bank concentration ratios, average net interest margins and z-scores as a measure of bank risk come from the Financial Structures Database by the World Bank (see Beck and Demirgüç-Kunt 2009 and Cihak et al. 2012).

Data on stocks of inward and outward foreign direct investment in the financial sector are available from the OECD. The measure of bank FDI used below consists of the sum of inward and outward FDI relative to GDP. For the 1995-2009 period, this data is available for 18 OECD countries. ${ }^{10}$ Information on cross-border bank loans

\footnotetext{
${ }^{9}$ Evidence from the European Central Bank (ECB, 2007) points into the same direction for the EU. In 2005, 46 European banking-groups (out of a total of 8,000 banks) held nearly 70 percent of total EU banking assets.

${ }^{10}$ These countries are Australia, Austria, Chile, Denmark, Finland, France, Germany, Greece, Ireland, Italy, Japan, South Korea, the Netherlands, Portugal, Sweden, Switzerland, Turkey, and the United States
} 
(assets and liabilities) is obtained from the International Investment Positions (IIP) of the International Monetary Fund. In analogy to the measure of bank FDI, I compute the ratio of the sum of assets and liabilities relative to GDP. I use two additional measures of foreign bank participation: The Chinn-Ito index of capital controls serves as a de jure measure of financial openness (see Chinn and Ito 2008). It gives information on legal and regulatory restrictions on cross-border financial transactions based on the IMF's Annual Report on Exchange Restrictions and Regulations. The Chinn-Ito index assumes values between -1.8 (financially closed) and 2.4 (financially open). Using data from on foreign bank ownership Claessens and van Horen (2013), I compute the share of foreign owned banks among the total number of banks for each country and year.

A set of macroeconomic control variables is taken from the World Development Indicators (WDI) by the World Bank.

[Table 4 about here.]

\subsection{International banking and concentration}

Using the data described above, this section studies whether more openness towards cross-border lending and bank FDI is indeed linked to lower concentration in domestic banking markets. Table 5 shows the results from country-fixed effects regressions with the Herfindahl-index based on loans as the dependent variable. I control for timefixed effects on a yearly basis in all regressions. The sample period for the baseline regressions is 1995-2006 in order to exclude the crisis period and, thereby, effects of government interventions on openness or market structures. Four alternative measures of international banking are included in the regressions, namely foreign bank loans relative to GDP as a proxy for foreign lending, FDI by financial intermediaries relative to GDP, the share of foreign banks, and the Chinn-Ito index. The set of macroeconomic and banking control variables consists of domestic credit relative to GDP, inflation, bank risk measured by the $\mathrm{z}$-score ${ }^{11}$, and bank capital relative to total assets. ${ }^{12}$

[Table 5 about here.]

Columns 1 and 2 show that both, foreign lending and bank FDI are negatively related to the Herfindahl-index. That is, the higher cross-border banking activity,

\footnotetext{
${ }^{11}$ The higher the z-score, the lower is bank risk. The z-score is given by the sum of the return on assets and equity to assets relative to the standard deviation of the return on assets. The higher the return on assets or equity to assets and the lower the volatility of the return on assets, the lower bank risk.

${ }^{12}$ Given that the variance inflation factor (VIF) for log GDP per capita suggests multicollinearity, I do not include this variable as a control. All other explanatory variables display VIF-values below 10 and hence tolerance values above 0.1 .
} 
the lower is concentration in the credit market. The share of foreign banks has no significant effect on the Herfindahl-index (column 3), whereas de jure openness for international banking significantly reduces credit market concentration in the sample. The link between the share of domestic credit relative to GDP, i.e. banking sector size, and concentration is positive. Lower bank risk (a higher z-score) comes along with lower concentration. However, the better capitalized a banking system is, the higher is the Herfindahl-index. This positive coefficient on capitalization may be interpreted as evidence for higher barriers to entry: If capital requirements are high, barriers to entry into the banking sectors are high, because a certain level of efficiency is required to be able to operate with higher capital and hence higher funding costs. If entry barriers are higher, contestability is lower which can increase concentration. Overall, the estimated coefficients should be interpreted as correlations rather than causal effects as I do not account for possible endogeniety issues here.

The standardized regression coefficients at the bottom of Table 5 reveal the economic significance of the different explanatory variables. To obtain standardized coefficients, I first normalize the dependent variable and each regressor by subtracting its mean and dividing by its standard deviation in order to eliminate units. In a second step, I re-run all regressions using the normalized variables. The estimated coefficients are hence comparable and indicate the economic significance of the different regressors in explaining the variation of the dependent variable.

Looking at column 5, which includes all regressors, it can be observed that the Chinn-Ito index has the strongest negative and significant effect on credit market concentration, followed by bank FDI. Bank capital relative to bank assets and domestic credit to GDP show an economically important positive link with concentration.

As an alternative measure of concentration, I use the three-bank concentration ratio from the Financial Structures Database (Table 6). While cross-border bank credit does not significantly affect three-bank concentration, bank FDI, the share of foreign banks and the Chinn-Ito index of capital controls significantly reduce concentration. The standardized coefficients at the bottom of the Table reveal that the three variables have high economic significance. Column 5 allows a comparison of the strengths of the different cross-border banking variables: The link between the share of foreign banks and three-bank concentration is economically most significant, followed by the Chinn-Ito index and bank FDI.

[Table 6 about here.]

In order to test whether the results are robust, the regression model is modified in several ways. When including the crisis-period (2007-2009), the results are somewhat weaker. However, the effects of cross-border lending and FDI remain significant and negative. Concerning the Herfindahl-index based on total assets instead of loans, the 
results are very similar to those for the Herfindahl-index based on total netloans presented in Table 5. Dropping years from the regression sample, one at a time, does not weaken the results; without the year 2000 or 2001, the effect of foreign lending on the Herfindahl-index turns negative and significant in the specification in column 5. The impact of all other regressors remains very similar to the baseline specification. The results are also broadly robust to dropping individual countries; without Switzerland, the coefficient on cross-border bank lending turns negative and significant in the specification presented in column 5. If only macroeconomic control variables are included in the baseline regression, the effect of cross-border lending become insignificant. Given that the effect is significant once banking variables like the z-score and capitalization are included, the estimated coefficient on cross-border banking may pick up opposing effects of banking characteristics in the setup with macroeconomic controls only.

Overall, cross-border banking thus coincides with lower banking sector concentration in the OECD countries. Hence, the data support the model predictions presented above. This finding is interesting, as it is not in line with the concern that increased financial openness leads to consolidation and hence to increased concentration. Moreover, the results differ from the findings of the trade literature for manufacturing firms, which suggests that more trade openness yields fiercer competition among exporters such that the least efficient firms exit the market and hence concentration increases (see for example Di Giovanni and Levchenko 2009).

\subsection{International banking and market power}

In order to examine the relationship between cross-border banking and market power, I regress net interest margins on the four different measures of cross-border banking, and on macroeconomic and banking variables for the period 1995-2006. The theoretical model proposes that more bank FDI coincides with higher markups, whereas more cross-border lending does not affect net interest margins. Table 7 presents the regression results. While higher inflation significantly increases net interest margins as found in the literature (for example Demirguc-Kunt and Huizinga 1999), higher bank capitalization and domestic credit relative to GDP tend to coincide with lower market power.

Among the cross-border banking measures, foreign bank loans and net interest margins are positively linked (column 1), but only the share of foreign banks has a statistically significant effect in the empirical model that includes all openness variables (column 5); the higher the share of foreign banks in the total number of banks in an economy, the higher are net interest margins. The standardized coefficients show that also in terms of economic significance, the share of foreign banks is highly important for the explanation of net interest margins, with the largest standardized coefficient 
among all regressors. This finding fits the theoretical implications discussed above. While cross-border lending does not affect bank markups under a Pareto-distribution of bank efficiency, cross-border bank mergers and acquisitions, or bank FDI, increase markups due to the resulting efficiency gains. The data for the OECD countries point into the same direction. ${ }^{13}$ Overall, the explanatory power of the model specifications presented in Table 7 is quite high with an $R^{2}$ of about 70 percent.

[Table 7 about here.]

The findings are robust to extending the sample period until 2009. Moreover, dropping individual countries or years from the regression sample does not affect the results. Including the z-score as a measure of bank risk significantly reduces the explanatory power of the model specifications presented in Table 7 , from about 70 percent to $35-50$ percent, the z-score being statistically insignificant. Therefore, I leave out this measure of bank risk in the baseline regressions. However, even if the z-score is included, the effect of the share of foreign banks remains positive and significant and the coefficient on bank FDI turns significantly positive in some specifications, too.

Overall, the regression results for the OECD countries are in line with the theoretical implications. While foreign bank ownership and bank markups are positively related, cross-border lending does not seem to matter much for net interest margins.

\section{Conclusions}

The aim of this paper is to analyze - both theoretically and empirically - the role international banking plays for market structures in the banking industry. The theoretical implications are based on a general equilibrium model with heterogeneous banks that lend to firms under imperfect competition. Cross-country evidence for 18 OECD economies over the period 1995-2009 is in line with the theory. Both foreign lending and foreign bank ownership coincide with lower concentration in the banking sector. By contrast, the implications of these two different modes of cross-border banking differ for the market power of banks. While foreign ownership increases average net interest margins, foreign lending does not seem to matter much for bank markups in the OECD.

My findings may inform the current debate on changes in the international regulation of the banking sector. The theoretical and empirical results suggest that crossborder banking and the associated international capital flows reduce concentration. Hence, policy initiatives that - explicitly or implicitly - limit international banking

\footnotetext{
${ }^{13}$ The fact that cross-border lending does not impact net interest margins may be interpreted as evidence in favor of a Pareto distribution of bank efficiency. Under a Fréchet distribution of bank efficiency parameters, an increase in contestability would reduce banks' markups rather than leaving them unaffected.
} 
should take the potential effects on bank market structure into account. Financial protectionism that reduces overall cross-border financial activity could lead to less contestability and hence to an increase in concentration. According to the granularity literature, increased concentration in the banking industry may lead to stronger variation in aggregate variables like credit, investment or GDP. If a reduction in cross-border bank activities leads to higher bank concentration, the link between volatility at the bank-level and macroeconomic volatility gets stronger. This, in turn, can have adverse effects on aggregate stability in the longer term. Moreover, the literature on bank competition comes to the conclusion that market contestability tends to increase financial stability which is another argument against more market segmentation in banking.

With respect to the different modes of international banking, bank FDI could be more stability-enhancing than cross-border lending, even though both modes reduce concentration. Following the "concentration-stability hypothesis", the increase in markups in case of FDI strengthens the resistibility of banks against adverse shocks: Higher markups boost banks' profits and thus provide a buffer against adverse shocks. Furthermore, higher markups increase the bank's charter value that may reduce its incentives to take excessive risks according to Keeley (1990) and others. This, in turn, reduces the probability of systemic banking crisis and thus supports stability in the financial system. In addition to this, in the model used here, the increase in markups under FDI does not imply an increase in concentration and lending rates; concentration and lending rates moderately fall if more bank FDI takes place. Following the argument by Boyd and De Nicolo (2005), if lending rates do not rise, there are no incentives for firms to assume greater risks.

However, it has to be kept in mind that these distinct mechanisms of banks' risktaking choices are not modeled in the framework presented here. Moreover, there are other important mechanisms affecting the stability of financial systems. For instance, adverse shocks to one region may spill-over to other regions if financial systems are linked by cross-border banking activities.

There are several tasks that could be addressed in future research. Modeling banks' risk taking explicitly in a framework with heterogeneous banks could allow to shed light on the stability implications of international banking. Another way of addressing stability issues could be to study granular effects in the banking sector in the openeconomy setup of the model. 


\section{References}

Allen, F., T. Beck, E. Carletti, P. Lane, D. Schoenmaker, and W. WagNER (2011): Cross-Border Banking in Europe: Implications for Financial Stability and Macroeconomic Policies, Centre for Economic Policy Research, London, ISBN: 978-1-907142-36-9.

Allen, F. And D. Gale (2004): "Competition and Financial Stability," Journal of Money, Credit and Banking, 36, 453-80.

Amiti, M. And D. Weinstein (2013): "How Much do Bank Shocks Affect Investment? Evidence from Matched Bank-Firm Loan Data," NBER Working Paper No. 18890 .

Anderson, S., A. De Palma, and J. Thisse (1987): "The CES is a discrete choice model?" Economics Letters, 24, 139-140.

Barth, J. R., G. Caprio JR, and R. Levine (2004): "Bank regulation and supervision: what works best?" Journal of Financial Intermediation, 13, 205-248.

BEck, T. (2008): "Bank competition and financial stability: friends or foes?" The World Bank, URI: http://hdl.handle.net/10986/6863.

Beck, T., D. Coyle, M. Dewatripont, X. Freixas, and P. Seabright (2010): Bailing out the banks: reconciling stability and competition, Center for Economic and Policy Research (CEPR), ISBN: 978-1-907142-03-1.

Beck, T. And A. DemirgüÇ-Kunt (2009): "Financial Institutions and Markets Across Countries and over Time: Data and Analysis," World Bank Policy Research Working Paper, 4943.

Beck, T., A. Demirguc-Kunt, and R. Levine (2006): "Bank concentration, competition, and crises: First results," Journal of Banking ES Finance, 30, 15811603.

Bernard, A., J. Eaton, J. Jensen, And S. Kortum (2003): "Plants and Productivity in International Trade," American Economic Review, 93, 1268-1290.

Boyd, J. AND G. De Nicolo (2005): "The theory of bank risk taking and competition revisited," Journal of Finance, 60, 1329-1343.

Bremus, F., C. Buch, K. Russ, And M. Schnitzer (2013): "Big Banks and Macroeconomic Outcomes: Theory and Cross-Country Evidence of Granularity," NBER Working Paper No. 19093. 
Bruggemann, B., J. Kleinert, and E. Prieto (2012): "The Ideal Loan and the Patterns of Cross-Border Bank Lending," Graz Economics Papers 2012-03, KarlFranzens University Graz, Department of Economics.

Buch, C. And K. Neugebauer (2011): "Bank-specific Shocks and the Real Economy," Journal of Banking \& Finance, 35, 2179-2187.

Carletti, E., P. Hartmann, and G. Spagnolo (2007): "Bank mergers, competition, and liquidity," Journal of Money, Credit and Banking, 39, 1067-1105.

Chinn, M. D. And H. Ito (2008): “A new measure of financial openness," Journal of Comparative Policy Analysis, 10, 309-322.

Cihak, M., A. DemirgüÇ-Kunt, E. Feyen, And R. Levine (2012): "Benchmarking Financial Development Around the World," World Bank Policy Research Working Paper, 6175.

Claessens, S. And L. Laeven (2004): "What drives bank competition? Some international evidence," Journal of Money, Credit and Banking, 563-583.

Clamessens, S. And N. van Horen (2013): "Foreign banks: Trends and Impact," Journal of Money, Credit, and Banking, Forthcoming.

Craig, B. And J. Santos (1997): "The risk effects of bank acquisitions," Economic Review-Federal Reserve Bank of Cleveland, 33, 25-35.

De Blas, B. And K. Russ (2010a): "FDI in the Banking Sector," NBER Working Papers No. 16029.

(2010b): "Understanding Markups in the Open Economy under Bertrand Competition," NBER Working Paper No. $1658 \%$.

DE Blas, B. And K. N. Russ (2013): "All banks great, small, and global: Loan pricing and foreign competition," International Review of Economics 63 Finance, 26, $4-24$.

Demirguc-Kunt, A. And H. Huizinga (1999): "Determinants of commercial bank interest margins and profitability: Some international evidence," The World Bank Economic Review, 13, 379-408.

DeYoung, R., D. D. Evanoff, And P. Molyneux (2009): "Mergers and acquisitions of financial institutions: a review of the post-2000 literature," Journal of Financial Services Research, 36, 87-110.

Di Giovanni, J. And A. Levchenko (2009): "Trade openness and volatility," The Review of Economics and Statistics, 91, 558-585. 
ECB (2007): "EU Banking Structures," Tech. rep., European Central Bank, ISSN 1830-1878 (online).

Gabaix, X. (2011): "The Granular Origins of Aggregate Fluctuations," Econometrica, 79, 733-772.

Gerali, A., S. Neri, L. Sessa, And F. Signoretti (2010): "Credit and Banking in a DSGE Model of the Euro Area," Journal of Money, Credit and Banking, 42, $107-141$.

Ghironi, F. And M. Melitz (2005): "International Trade and Macroeconomic Dynamics with Heterogeneous Firms," The Quarterly Journal of Economics, 120, 865915.

Ghironi, F. And V. Stebunovs (2010): "The Domestic and International Effects of Interstate U.S. Banking," NBER Working Paper No. 16613.

Hellmann, T. F., K. C. Murdock, And J. E. Stiglitz (2000): "Liberalization, moral hazard in banking, and prudential regulation: Are capital requirements enough?" American Economic Review, 147-165.

Huelsewig, O., E. Mayer, and T. Wollmershaeuser (2009): "Bank behavior, incomplete interest rate pass-through, and the cost channel of monetary policy transmission," Economic Modelling, 26, 1310-1327.

Jeon, B. N., M. Olivero, And J. Wu (2011): "Do foreign banks increase competition? Evidence from emerging Asian and Latin American banking markets," Journal of Banking $\&$ Finance, 35, 856-875.

Keeley, M. C. (1990): "Deposit insurance, risk, and market power in banking," The American Economic Review, 1183-1200.

Malik, H. And R. Trudel (1982): "Probability density function of quotient of order statistics from the pareto, power and weibull distributions," Communications in Statistics-Theory and Methods, 11, 801-814.

Mandelman, F. S. (2010): "Business Cycles: A Role for Monopolistic Competition in the Banking Sector." Journal of International Economics, 81, 122-138.

Matutes, C. And X. Vives (1996): "Competition for deposits, fragility, and insurance," Journal of Financial Intermediation, 5, 184-216.

Merler, S. And J. Pisani-Ferry (2012): "Who's Afraid of Sovereign Bonds," Bruegel Policy Contribution, 2012-2.

Mishkin, F. S. (1999): "Financial consolidation: Dangers and opportunities," Journal of Banking $\&$ Finance, 23, 675-691. 
PARoush, J. (1995): "The effect of merger and acquisition activity on the safety and soundness of a banking system," Review of Industrial Organization, 10, 53-67.

Pockrandt, J. And S. Radde (2012): "Need for reform of EU banking: Decoupling the solvency of banks and sovereigns," DIW Economic Bulletin, 2, 11-18.

Rose, A. And T. Wieladek (2011): "Financial Protectionism: the First Test," NBER Working Paper No. 17073.

Vander Vennet, R. And R. Gropp (2003): "Cross-Border Mergers in European Banking and Bank Efficiency," in Foreign direct investment in the real and financial sector of industrial countries, ed. by H. Herrmann and R. Lipsey, Springer, 295-321. 


\section{A Appendix}

\section{A.1 Optimization problems}

\section{A.1.1 Households}

Solving the households' optimization problem with respect to the three choice variables $q_{t}, h_{t}, d_{t+1}$ yields, together with the budget contraint (1), the following system of first order conditions for optimal consumption, labor supply and savings:

$$
\begin{aligned}
q_{t}^{-\rho} & =\lambda_{t} \\
h_{t}^{1 / \gamma} & =\lambda_{t} w_{t} \\
\lambda_{t} & =\beta \lambda_{t+1}\left(1+r^{d}\right)
\end{aligned}
$$

where $\lambda_{t}$ represents the additional utility of relaxing the budget constraint by one unit, i.e. the marginal utility of consumption.

Plugging marginal utility (12) into (14) yields the standard Euler equation

$$
\left(\frac{q_{t}}{q_{t+1}}\right)^{-\rho}=\left(1+r^{d}\right) \beta
$$

which determines the optimal intertemporal allocation of consumption. The marginal benefit of consuming one additional unit in period $t$ equals the marginal cost of foregoing consumption in period $t+1$.

To obtain labor supply, substitute (12) into (13) to get

$$
q_{t}^{\rho}=w_{t} h_{t}^{-1 / \gamma} .
$$

\section{A.1.2 Firms}

The optimal demand for loans from bank $j$ results from the firm's cost minimization calculus

$$
\min _{l^{d}(j)} \quad \mathcal{L}=\sum_{1}^{J} l^{d}(j) r(j)-\mu\left(\left[\sum_{1}^{J} l^{d}(j)^{\frac{\epsilon-1}{\epsilon}}\right]^{\frac{\epsilon}{\epsilon-1}}-\ell^{d}\right),
$$

where $\epsilon$ is the intratemporal elasticity of substitution between the $J$ credit varieties. Derivation of the Lagrangian with respect to loan demand from bank $j, l^{d}(j)$, yields the following first order condition

$$
r(j)=\mu\left(\ell^{d}\right)^{1 / \epsilon} l^{d}(j)^{-1 / \epsilon},
$$

where $\mu$ is the shadow price of the constraint, that is, the amount that is spend more if total loan demand $l^{d}$ increases by one unit. This is the aggregate interest rate on 
loans, $r$, such that $\mu=r$. Plugging $r$ into (18) and simplifying, we obtain the demand for loans in niche $j$

$$
l^{d}(j)=\left[\frac{r(j)}{r}\right]^{-\epsilon} \ell^{d}
$$

with $\ell^{d}=w h$. Loan demand in niche $j$ positively depends on total loan demand $\ell^{d}$. It negatively depends on the lending rate in niche $j$ relative to the aggregate average lending rate $r$.

\section{A.1.3 Banks}

Banks maximize profits by setting the optimal lending rate $r(j)$. Recall that bank technology is given by $l^{s}(j)=\frac{(1+e) d(j)}{c(j)}$. Rewriting this equation and substituting $d(j)$ into the bank profit function yields

$$
\Pi(j)=r(j) l^{s}(j)-\frac{\left[r^{d}+r^{e} e\right] c(j)}{1+e} l^{s}(j) .
$$

Deriving this expression with respect to the lending rate $r(j)$ and setting the derivative equal to zero, I obtain

$$
\frac{\partial \Pi(j)}{\partial r(j)}=l(j)+r(j) \frac{\partial l(j)}{\partial r(j)}-\frac{\left[r^{d}+r^{e} e\right] c(j)}{1+e} \frac{\partial l(j)}{\partial r(j)},
$$

where $\frac{\partial l(j)}{\partial r(j)}=-\epsilon l(j) / r(j)$. Hence,

$$
\begin{aligned}
\frac{\partial \Pi(j)}{\partial r(j)} & =l(j)-\epsilon l(j)+\epsilon \frac{\left[r^{d}+r^{e} e\right] c(j)}{1+e} \frac{l(j)}{r(j)} \equiv 0 \\
\epsilon-1 & =\epsilon \frac{\left[r^{d}+r^{e} e\right] c(j)}{1+e} \frac{1}{r(j)} \\
r(j) & =\frac{\epsilon}{\epsilon-1} \frac{\left[r^{d}+r^{e} e\right] c(j)}{1+e}
\end{aligned}
$$

where $\frac{\epsilon}{\epsilon-1}$ is the constant Dixit-Stiglitz markup and $\frac{\left[r^{d}+r^{e} e\right] c(j)}{1+e}$ is the marginal cost of lending.

\section{A.2 Derivation of the Dixit-Stiglitz aggregate interest rate}

Knowing that aggregate loan demand is given by $\ell^{d}=\left[\sum_{1}^{J} l^{d}(j)^{\frac{\epsilon-1}{\epsilon}}\right]^{\frac{\epsilon}{\epsilon-1}}$, take (18) to the power of $-(\epsilon-1)$ to get $l^{d}(j)^{\frac{\epsilon-1}{\epsilon}}$ :

$$
r(j)^{-(\epsilon-1)}=r^{-(\epsilon-1)}\left(\ell^{d}\right)^{\frac{-\epsilon-1}{\epsilon}} l^{d}(j)^{\frac{\epsilon-1}{\epsilon}} .
$$

Take the sum from 1 to $J$ over (25) to get

$$
\sum_{1}^{J} r(j)^{-(\epsilon-1)}=r^{-(\epsilon-1)}\left(\ell^{d}\right)^{\frac{-\epsilon-1}{\epsilon}} \sum_{1}^{J} l^{d}(j)^{\frac{\epsilon-1}{\epsilon}}
$$


and isolate $r$ by taking the above equation to the power of $-\frac{1}{\epsilon-1}$ :

$$
\begin{aligned}
{\left[\sum_{1}^{J} r(j)^{1-\epsilon}\right]^{\frac{1}{1-\epsilon}} } & =r\left(l^{d}\right)^{\frac{1}{\epsilon}}\left[\sum_{1}^{J} l^{d}(j)^{\frac{\epsilon-1}{\epsilon}}\right]^{\frac{1}{1-\epsilon}} \\
\Leftrightarrow\left[\sum_{1}^{J} r(j)^{1-\epsilon}\right]^{\frac{1}{1-\epsilon}} & =r\left(\ell^{d}\right)^{1 / \epsilon}\left(l^{d}\right)^{-1 / \epsilon} \\
\Leftrightarrow r & =\left[\sum_{1}^{J} r(j)^{1-\epsilon}\right]^{\frac{1}{1-\epsilon}}
\end{aligned}
$$

\section{A.3 Steady State in the closed economy}

As a first step, compute labor supply $h^{s}$ as a function of the wage rate $w$. For this goal, substitute $q$ from the labor supply equation (9) and $y$ from the production function in the aggregate resource constraint $y=q$ and solve for $h(w)$ :

$$
\begin{array}{r}
y \equiv q \\
A h^{1-\alpha}=w^{1 / \rho} h^{-\frac{1}{\gamma \rho}} \\
h^{\frac{(1-\alpha) \gamma \rho+1}{\gamma \rho}}=w^{1 / \rho} A^{-1} \\
h^{s}=w^{\frac{\gamma}{(1-\alpha) \gamma \rho+1}} A^{-\frac{\gamma \rho}{(1-\alpha) \gamma \rho+1}}
\end{array}
$$

set $1+(1-\alpha) \gamma \rho=x$ and substitute to get

$$
h^{s}(w)=w^{\frac{\gamma}{x}} A^{-\frac{\gamma \rho}{x}} .
$$

As a second step, compute the wage $w$ as a function of the aggregate lending rate $r$ :

$$
\begin{aligned}
h^{d}(w) & \equiv h^{s}(w) \\
{\left[\frac{(1-\alpha) A}{(1+r) w}\right]^{1 / \alpha} } & =w^{\frac{\gamma}{x}} A^{-\frac{\gamma \rho}{x}} \\
w^{\frac{x+\alpha \gamma}{\alpha x}} & =A^{\frac{x+\alpha \gamma \rho}{\alpha x}}\left[\frac{1-\alpha}{1+r}\right]^{1 / \alpha} \quad \text { take }(\cdots)^{\frac{\alpha x}{x+\alpha \gamma}} \\
w=w(r) & =A^{\frac{x+\alpha \gamma \rho}{\alpha \gamma+x}}\left[\frac{1-\alpha}{1+r}\right]^{\frac{x}{\alpha \gamma+x}} \\
\Leftrightarrow w(r) & =A^{\frac{1+\gamma \rho}{\alpha \gamma+x}}\left[\frac{1-\alpha}{1+r}\right]^{\frac{x}{\alpha \gamma+x}} .
\end{aligned}
$$

Step three consists in substituting $w$ into labor supply (34) to get employment as a function of $r$.

$$
\begin{aligned}
h & =\left[A^{\frac{1+\gamma \rho}{\alpha \gamma+x}}\left[\frac{1-\alpha}{1+r}\right]^{\frac{x}{\alpha \gamma+x}}\right]^{\frac{\gamma}{x}} A^{-\frac{\gamma \rho}{x}} \\
\Leftrightarrow h(r) & =\left[\frac{1-\alpha}{1+r}\right]^{\frac{\gamma}{\alpha \gamma+x}} A^{\frac{(1+\gamma \rho) \gamma}{(x+\alpha \gamma) x}-\frac{\gamma \rho}{x}}
\end{aligned}
$$


Further simplify the exponent of $A$ :

$$
\frac{(1+\gamma \rho) \gamma-\gamma \rho(x+\alpha \gamma)}{(x+\alpha \gamma) x}=\frac{\gamma[(1+\gamma \rho)-\rho(x+\alpha \gamma)]}{x(x+\alpha \gamma)}
$$

and rewrite the nominator as

$$
\begin{aligned}
& \gamma\left[1+\gamma \rho-\rho-(1-\alpha) \gamma \rho^{2}-\rho \alpha \gamma\right] \\
= & \gamma[\underbrace{1+\gamma \rho(1-\alpha)}_{x}-\rho \underbrace{(1+(1-\alpha) \gamma \rho)}_{x}] \\
= & \gamma[(1-\rho) x] .
\end{aligned}
$$

Hence, the employment equation (41) simplifies to

$$
h=\left[\frac{1-\alpha}{1+r}\right]^{\frac{\gamma}{\alpha \gamma+x}} A^{\frac{\gamma(1-\rho)}{x+\alpha \gamma}} .
$$

Finally, plug $h(r)$ into production $y$ to get $y=q$ as a function of $r$ :

$$
\begin{aligned}
y & =A h^{1-\alpha}=A\left(\left[\frac{1-\alpha}{1+r}\right]^{\frac{\gamma}{\alpha \gamma+x}} A^{\frac{\gamma(1-\rho)}{x+\alpha \gamma}}\right)^{1-\alpha} \\
\Leftrightarrow y(r) & =\left[\frac{1-\alpha}{1+r}\right]^{\frac{\gamma(1-\alpha)}{\alpha \gamma+x}} A^{1+\frac{\gamma(1-\rho)(1-\alpha)}{x+\alpha \gamma}}=q(r)
\end{aligned}
$$

The aggregate lending rate $r$ is determined above from aggregation of lending rates in each niche $j$ (see equation (7)).

\section{A.4 Distributions of model variables}

Each bank draws its efficiency parameter $z(j)$ from an i.i.d. bounded Pareto function of the form

$$
F(z)=\frac{1-z_{0}^{\theta} z^{-\theta}}{1-z_{0}^{\theta}}
$$

with support $(0,1]$. The mimimum of $z$ equals $z_{0}=0.1$ while the maximum is fixed at 1. This implies that the marginal cost of lending one unit, $\frac{\left(r^{d}+r^{e} e\right) c}{1+e}$, is greater than the bank's funding $\operatorname{cost} \frac{\left(r^{d}+r^{e} e\right)}{1+e}$, i.e. that $c>1$. Hence, the probability that $c<1$, $F(z>1)=0$.

How to draw efficiency-parameters from the Pareto function

Since the cost parameter $c$ needs to be greater or equal to 1 , the support of the efficiency parameter $z=1 / c$ is limited to $z \in\left(z_{0}, 1\right]$. Hence, the Pareto distribution needs to be limited with the lower bound $z_{0}=0.1$ as above and an upper bound equal to one. The 
corresponding bounded Pareto function is given by

$$
\begin{aligned}
F(z)=\operatorname{Pr}(z \leq y) & =\frac{1-z_{0}^{\theta} z^{-\theta}}{1-z_{0}^{\theta}} \\
\left(1-z_{0}^{\theta}\right) F(z) & =1-z_{0}^{\theta} z^{-\theta} \\
z & =z_{0}\left[1-\left(1-z_{0}^{\theta}\right) F(z)\right]^{-\frac{1}{\theta}}
\end{aligned}
$$

where $F(z)$ takes on values on the interval $[0,1]$.

Deriving the distribution of the markup

Following Malik and Trudel (1982), the quotient of two order statistics that are independently drawn from a Pareto distribution can be derived as follows.

Given that efficiency $\mathbf{Z} \sim$ Pareto with support $[\mathbf{0}, \infty]$, i.e. $\mathbf{C} \in[\mathbf{0}, \infty]$, the first step consists in deriving the $P D F$ of the ratio $Q=\frac{Z_{i}}{Z_{j}}$ where $i<j$ and $Z_{1}<Z_{2}<\ldots<Z_{n}$. According to Malik and Trudel (1982), the PDF of $Q$ is given by

$$
h(q)=\frac{\theta q^{\theta-\theta n-\theta j-1}}{\beta(j-i, n-j+1)}\left(1-q^{\theta}\right)^{j-i-1},
$$

where $\beta(a, b)$ is the Beta-function $\beta(a, b)=\frac{(a-1) !(b-1) !}{(a+b-1) !}$. As I want to compute $h(q)$ for the highest and the second-highest efficiency level, I set $i=n-1$ and $j=n$, so that (53) can be rewritten as

$$
\begin{aligned}
h_{n-1, n}(q) & =\frac{\theta q^{\theta-\theta n-\theta n-1}}{\beta(1,1)}\left(1-q^{\theta}\right)^{0} \\
& =\theta q^{\theta-1}
\end{aligned}
$$

To compute the $C D F$ of $0<Q<1$, integrate $h(q)$, such that

$$
\begin{aligned}
H(q) & =\theta \int_{0}^{q} x^{\theta-1} d x=\theta\left[\frac{1}{\theta} x^{\theta}\right]_{0}^{q} \\
& =q^{\theta} .
\end{aligned}
$$

Let us now turn to the ratio $\tilde{M}=\frac{C_{2}}{C_{1}}=1 / Q$. The complementary distribution of $\tilde{M}$ is given by

$$
\begin{aligned}
F^{c}(\tilde{m}) & =\operatorname{Pr}(\tilde{M} \geq \tilde{m}) \\
& =\operatorname{Pr}(1 / Q \geq \tilde{m})=\operatorname{Pr}(Q \leq 1 / \tilde{m}) \\
& =H\left(\tilde{m}^{-1}\right)
\end{aligned}
$$

Hence, I have that

$$
F(\tilde{m})=1-F^{c}(\tilde{m})=1-H\left(\tilde{m}^{-1}\right)=1-\left(\frac{1}{\tilde{m}}\right)^{\theta}
$$

which shows that the cost-ratio $\tilde{M}=C_{2} / C_{1}$ follows a Pareto-distribution with minimum $z_{0}=1$. The distribution of the markup $M$ thus also follows a Pareto-distribution. 
However, it is truncated at the Dixit-Stiglitz markup $\bar{m}$, such that

$$
F(m)=\operatorname{Pr}(M \leq m) \begin{cases}1-\left(\frac{1}{m}\right)^{\theta} & \text { if } 1 \leq m<\bar{m} \\ 1 & \text { if } m \geq \bar{m}\end{cases}
$$

This is the same result as in De Blas and Russ (2010b) and in Bernard et al. (2003). The probability of observing the maximum markup is independent of the number of rivals $n$. As dispersion increases ( $\theta$ falls), the probability of observing the maximum markup, $\operatorname{Pr}[M(j) \geq \bar{m}]=1-\operatorname{Pr}[M(j) \leq \bar{m}]=\bar{m}^{-\theta}$ increases. 
Table 1: Parameter values

\begin{tabular}{lll}
\hline Parameter & Value & Description \\
\hline$\theta$ & 4.3 & Shape parameter of the distribution of efficiency levels \\
$\epsilon$ & 4.3 & Elasticity of substitution between credit varieties \\
$\mathrm{n}$ & {$[2,100]$} & Number of rivals per niche \\
$\mathrm{J}$ & 100 & Number of niches \\
$\gamma$ & 1 & Elasticity of labor supply \\
$\rho$ & 2 & Coefficient of relative risk aversion \\
$\beta$ & 0.98 & Subjective discount factor \\
$r^{d}$ & 0.02 & Deposit rate \\
$1-\alpha$ & 0.64 & Labor share of income \\
$z_{0}$ & 0.1 & Lower bound of Pareto distribution of bank efficiency \\
$e$ & 0.1 & Bank capital as a fraction of deposits \\
$r^{e}$ & 0.06 & Interest rate on bank equity \\
& & \\
\hline
\end{tabular}


Table 2: Values of aggregate variables for different levels of contestability

\begin{tabular}{cccccc}
\hline $\mathbf{n}$ & $\begin{array}{c}\text { Markup } \\
(m)\end{array}$ & $\begin{array}{c}\text { Lending } \\
\text { rate }(r)\end{array}$ & $\begin{array}{c}\text { Domestic } \\
\text { credit }(\ell)\end{array}$ & $\begin{array}{c}\text { Herfindahl } \\
\text { index } \\
(\sqrt{H H I})\end{array}$ & $\begin{array}{c}\text { 3-bank con- } \\
\text { centration }\end{array}$ \\
\hline $\mathbf{1 0 0}$ & 1.18 & 0.02 & 0.561 & 0.005 & 0.097 \\
$\mathbf{1 0}$ & 1.18 & 0.03 & 0.553 & 0.017 & 0.144 \\
$\mathbf{2}$ & 1.18 & 0.04 & 0.545 & 0.025 & 0.154 \\
& & & & &
\end{tabular}

This Table shows simulated average outcomes for markups $m$, lending rates $r$, loan volumes $\ell$, the squareroot of the Herfindahl-index, $\sqrt{H H I}$, and the three-bank concentration ratio. $n$ denotes the number of rivals per niche, i.e. contestability. 
Table 3: Concentration of Bank Assets in OECD Countries

\begin{tabular}{cccc}
\hline & & \multicolumn{2}{c}{ Percent of assets held by... } \\
Year & Number of banks & $\begin{array}{c}\text { largest } \begin{array}{c}\text { 1\% of } \\
\text { banks }\end{array} \\
\text { banks }\end{array}$ \\
\hline 1995 & 3,633 & 57.3 & 85.8 \\
1996 & 3,708 & 54.7 & 85.5 \\
1997 & 3,766 & 55.7 & 86.9 \\
1998 & 3,909 & 55.0 & 86.9 \\
1999 & 13,571 & 66.3 & 90.8 \\
2000 & 13,622 & 66.8 & 91.0 \\
2001 & 13,547 & 69.1 & 91.3 \\
2002 & 14,047 & 70.0 & 91.2 \\
2003 & 14,171 & 71.4 & 92.1 \\
2004 & 14,129 & 74.3 & 93.4 \\
2005 & 15,076 & 73.2 & 93.9 \\
2006 & 13,645 & 71.8 & 93.5 \\
2007 & 13,489 & 72.2 & 93.8 \\
2008 & 13,111 & 73.3 & 94.3 \\
2009 & 12,554 & 72.6 & 94.2 \\
& & & \\
\hline
\end{tabular}

This table shows the evolution of asset concentration for an unbalanced panel of 18 OECD countries for the period 1995-2009. The higher the share of assets held by the largest $\mathrm{x} \%$ of banks in the OECD, the higher concentration. 


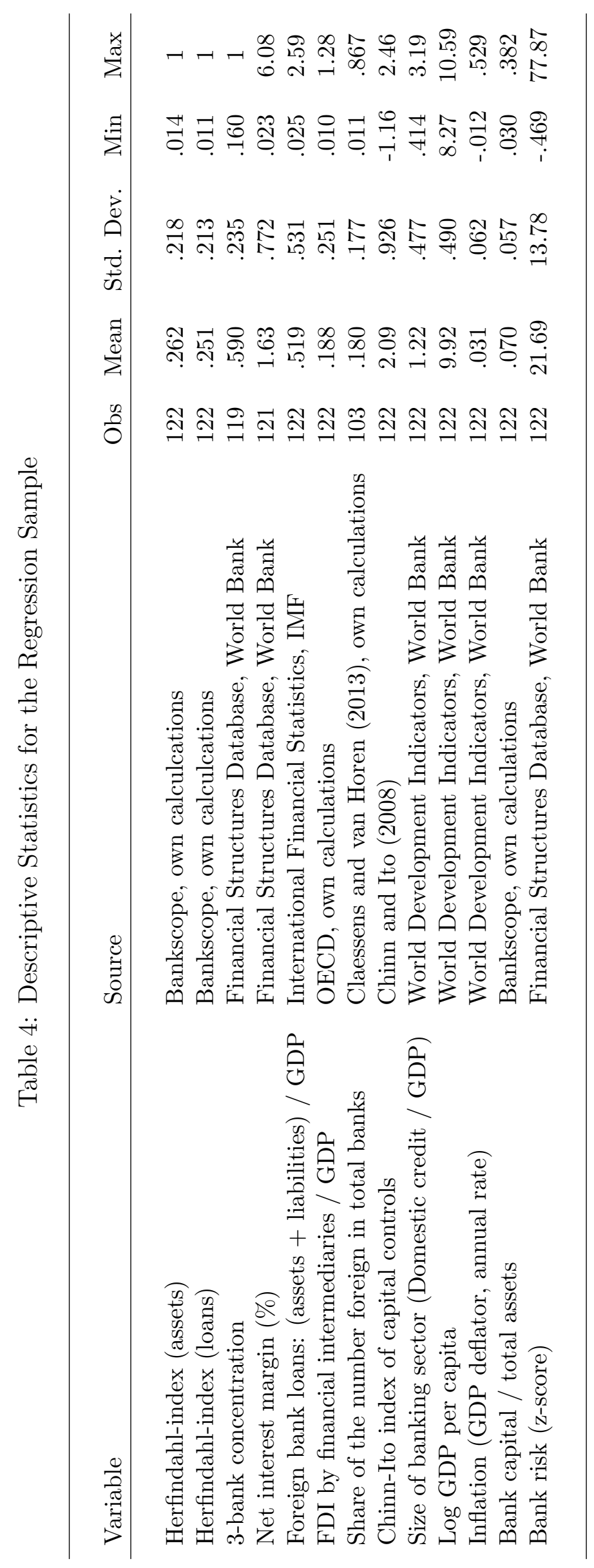




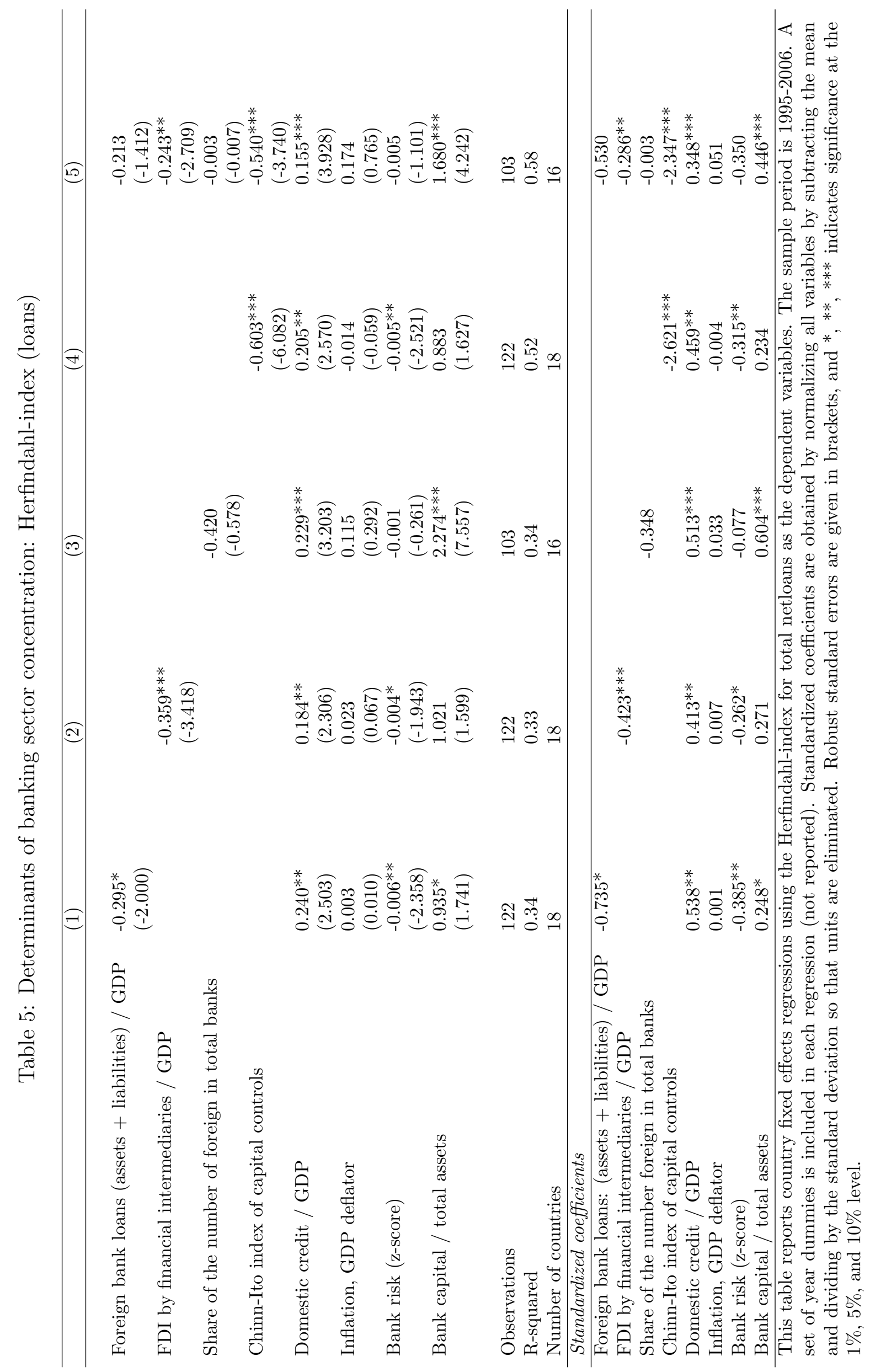




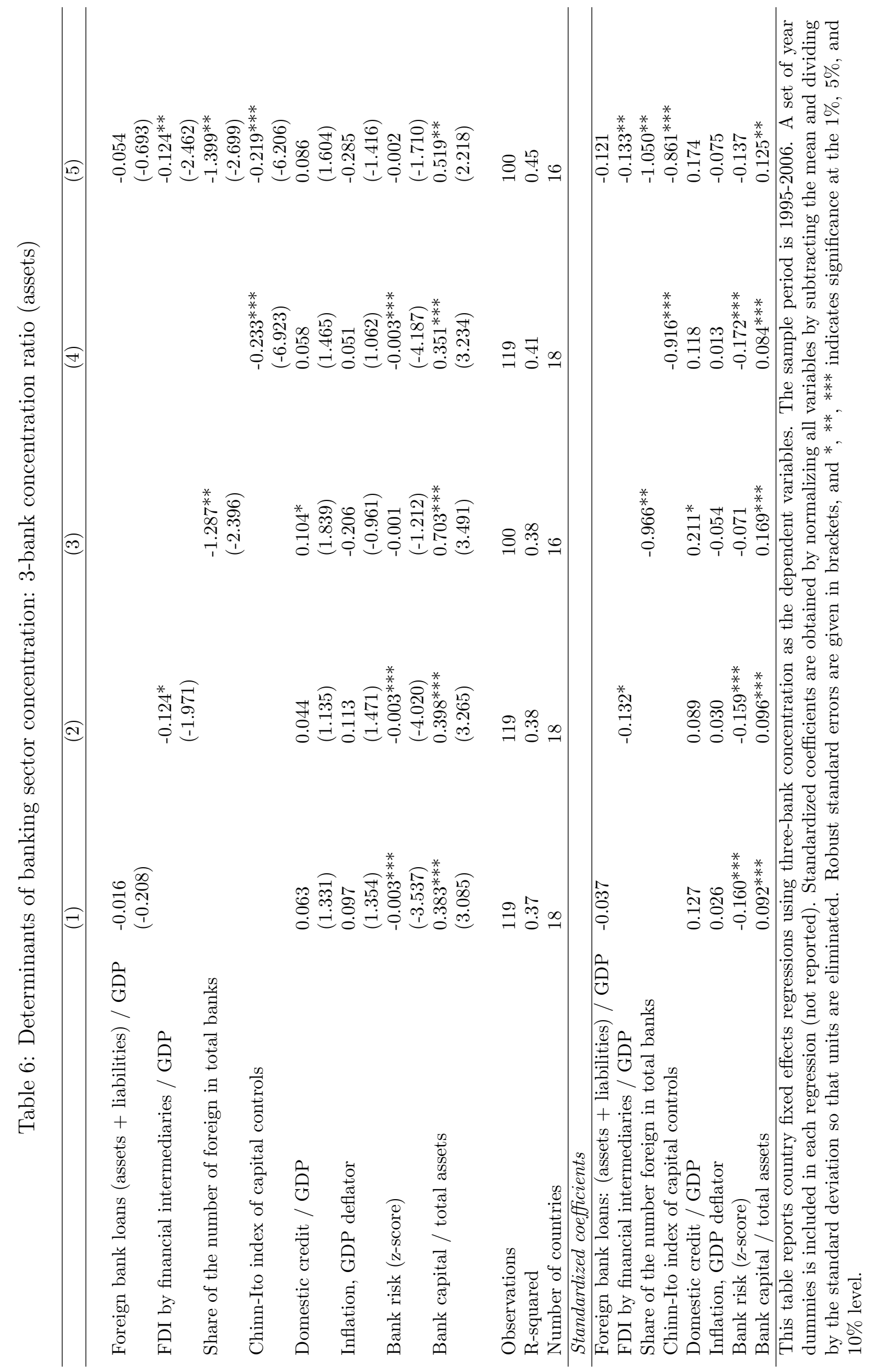




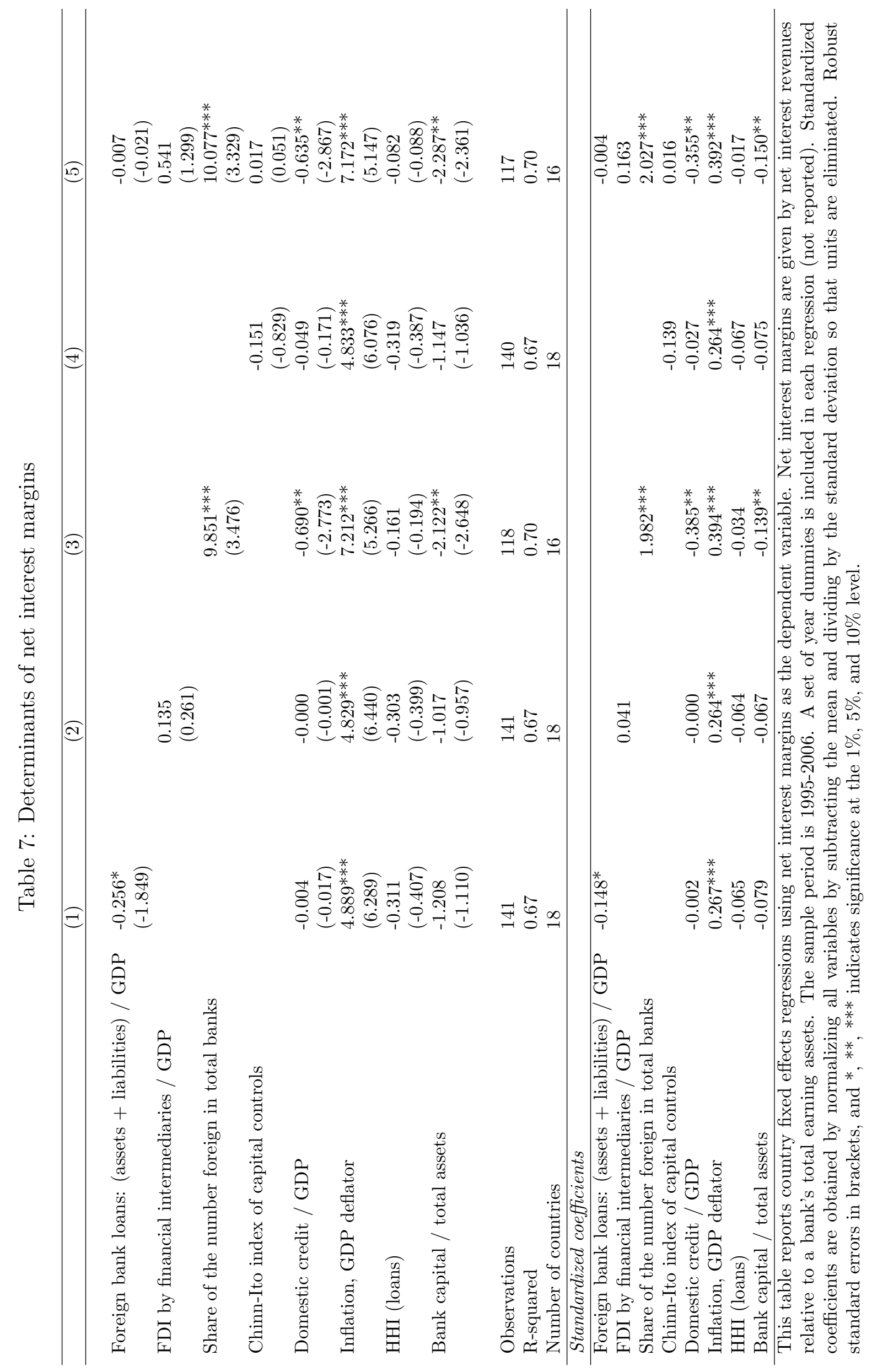


Figure 1: International Banking

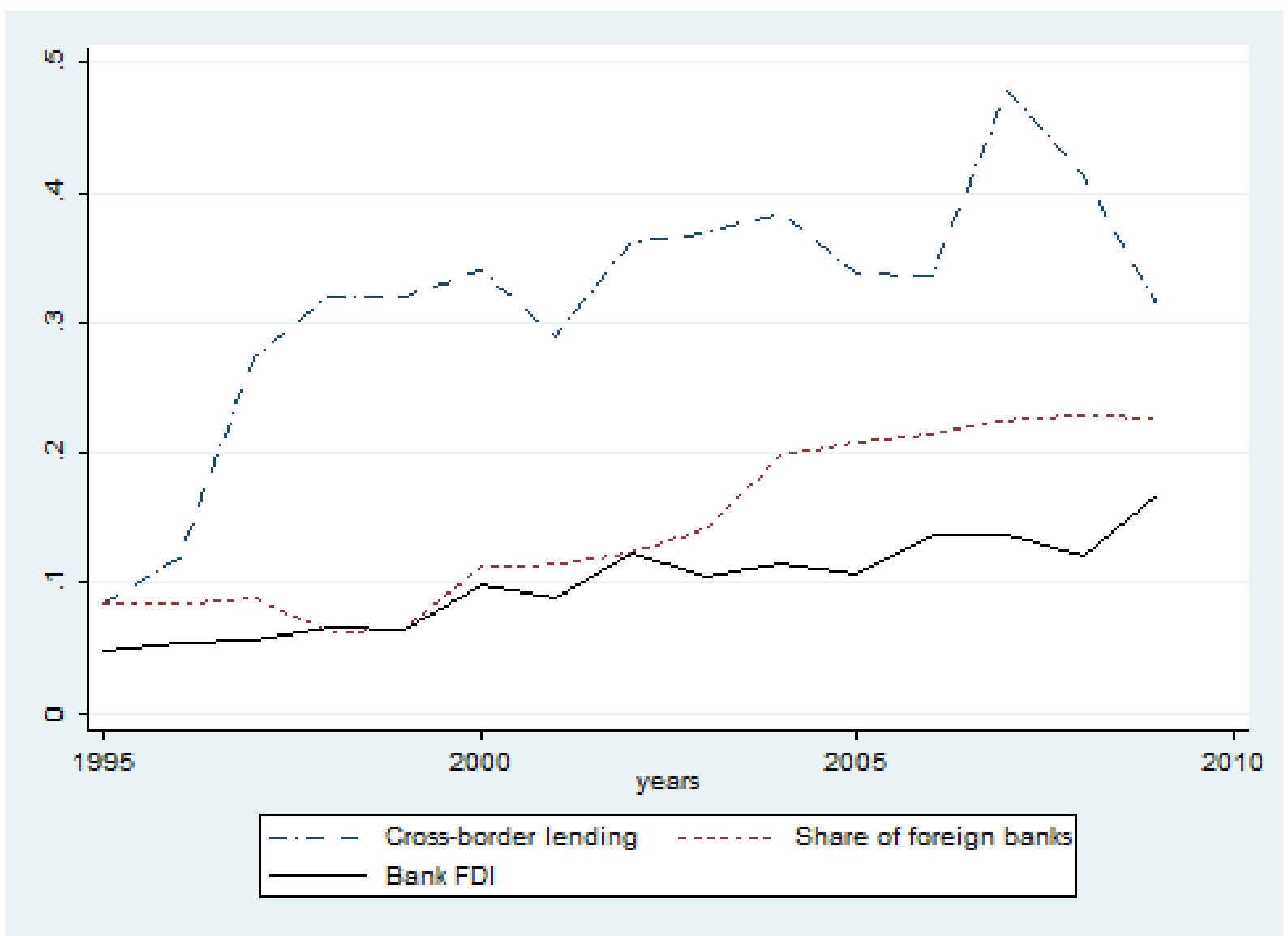

This Figure shows different measures of international banking for 18 OECD countries. Data on cross-border lending is taken from the Balance of Payments Statistics by the IMF. It denotes the sum of banks' loans (assets plus liabilities) relative to a country's GDP. Bank FDI includes outwardand inward FDI of financial intermediaries relative to GDP. The data are publicly available from the OECD. The share of foreign banks measures the number of foreign bank in the total number of banks in a given country. It is computed from data provided by Claessens and van Horen (2013). The lines depict the median values across the 18 OECD countries. 
Figure 2: Empirical Histograms of Bank Sizes in the OECD
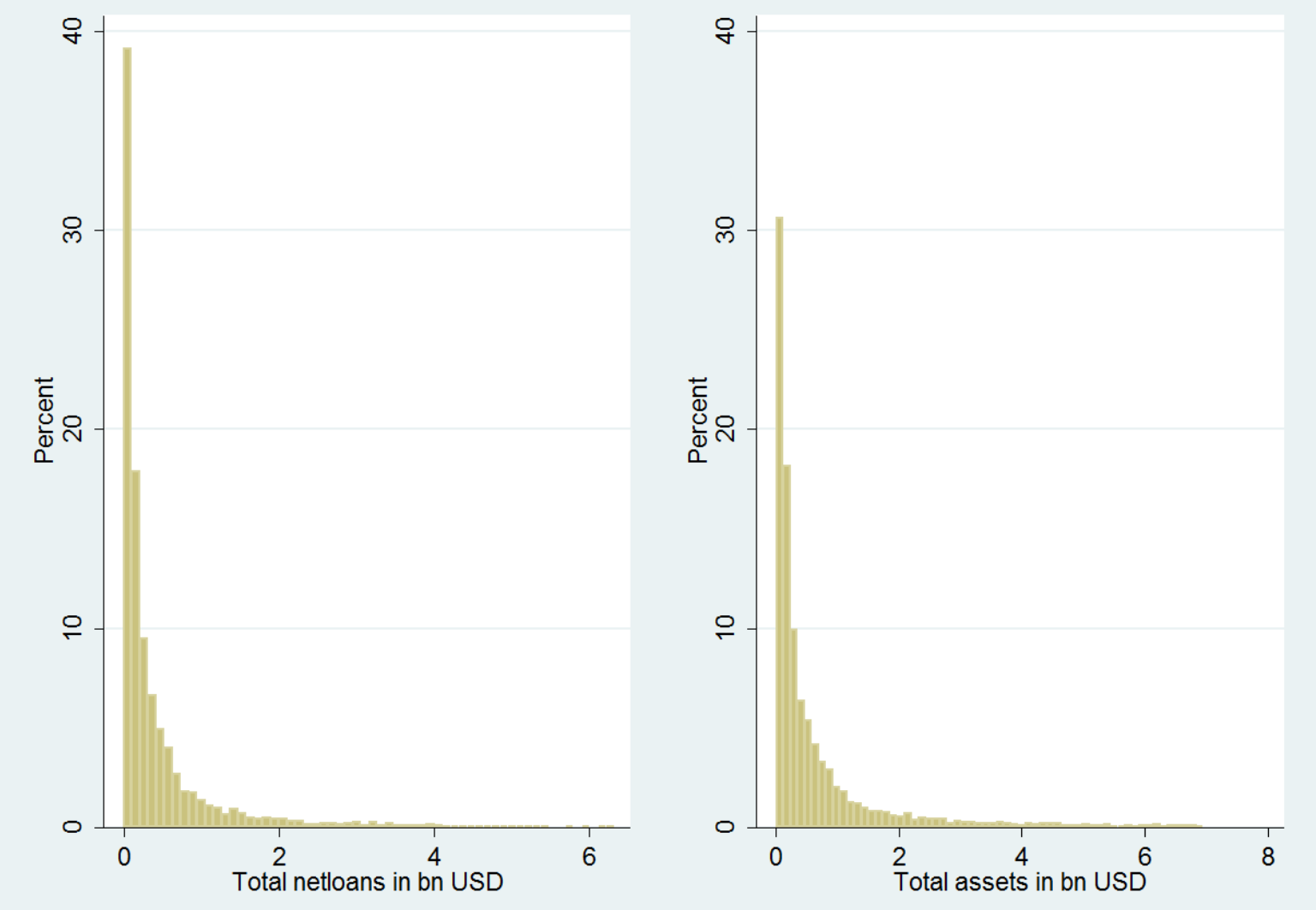

This Figure displays the empirical distribution of bank sizes based on (a) loans and (b) on assets in billion USD for 18 OECD countries. The top $5 \%$ of banks are not plotted for reasons of visibility. 
Figure 3: CDFs and PDF under autarky
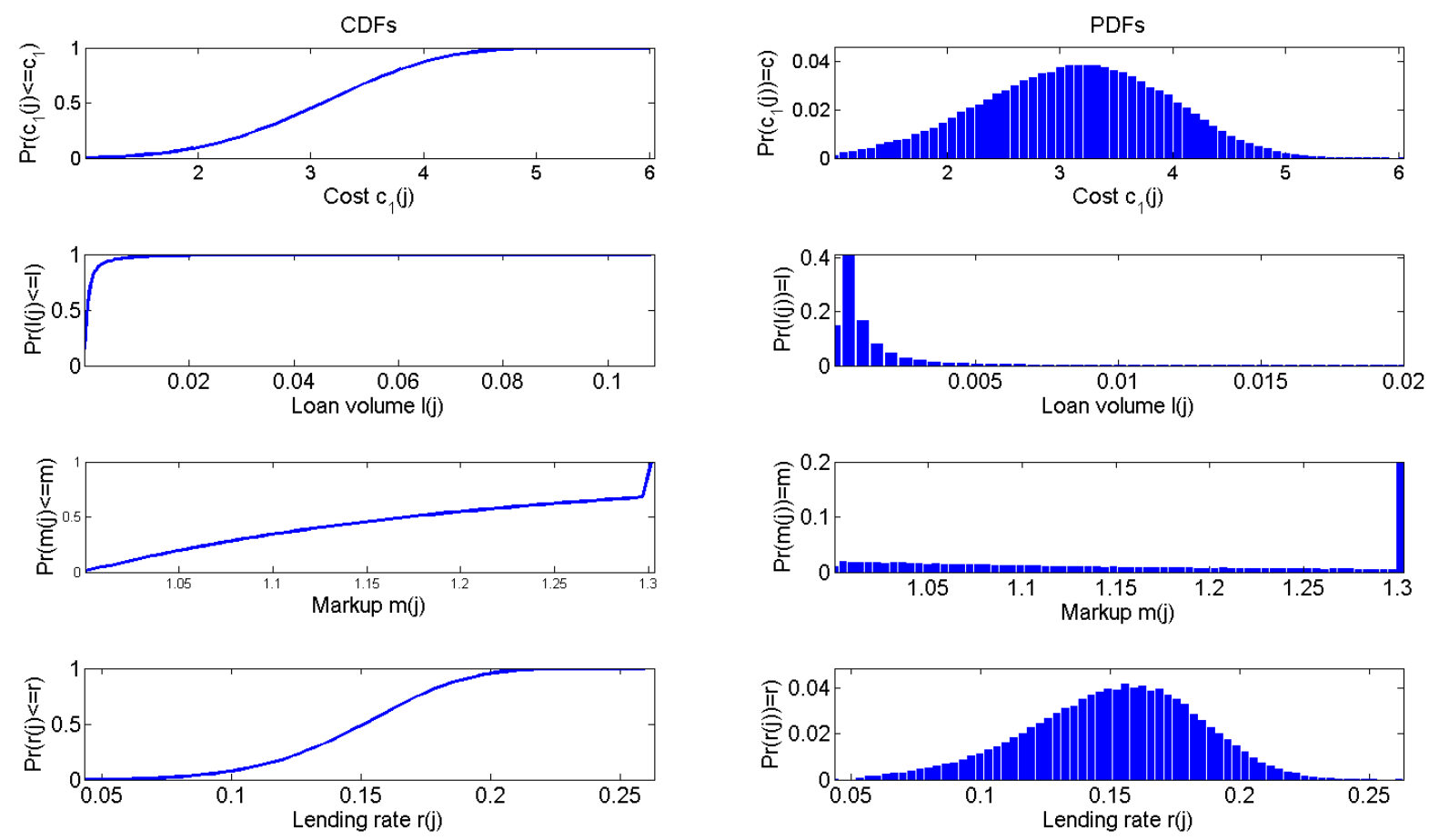
Figure 4: CDFs and PDFs for the closed and open economy, with and without distance factor
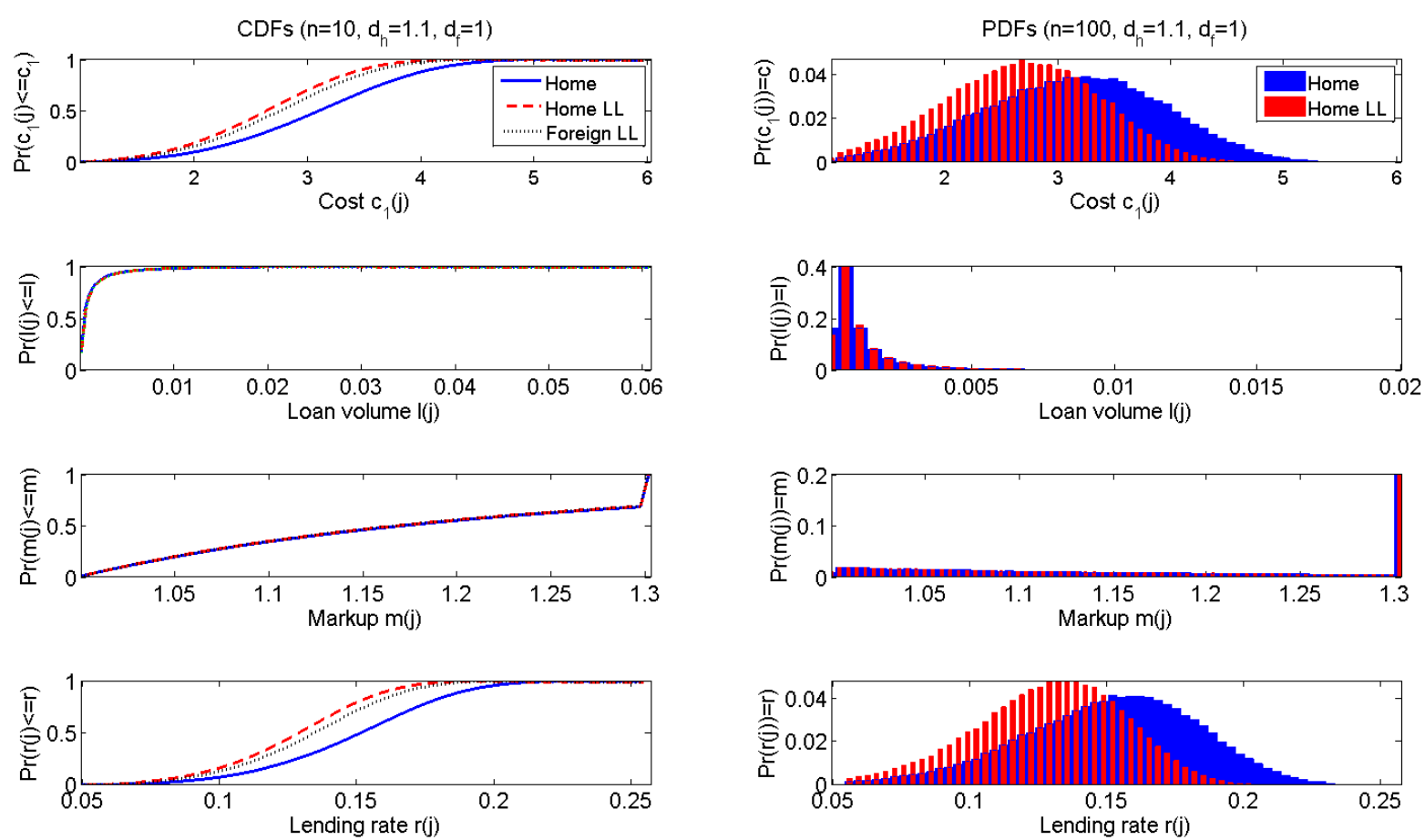
Figure 5: CDFs and PDFs: Closed economy vs. bank FDI
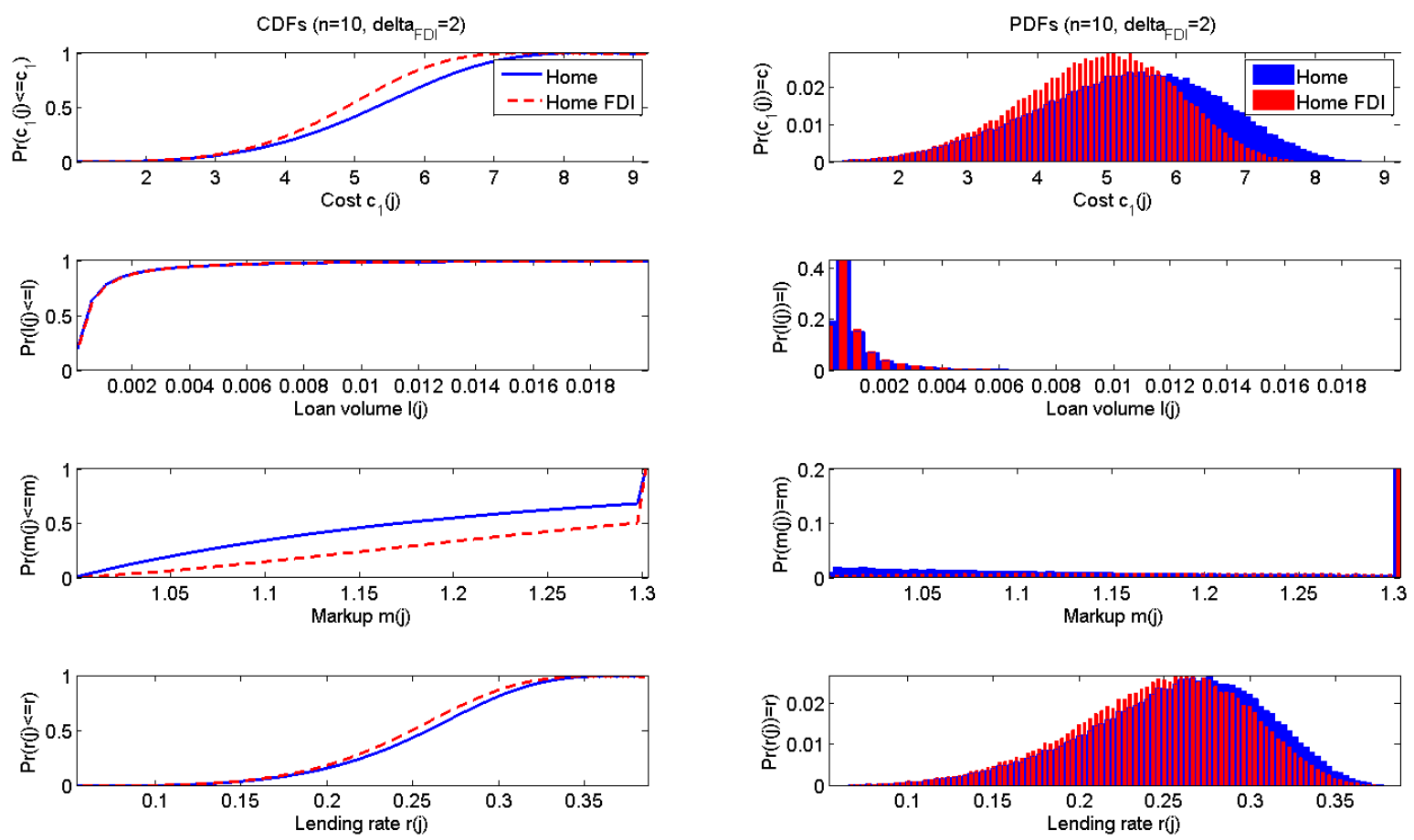